\title{
Ionic Liquids in Separation of Metal Ions from Aqueous Solutions
}

\author{
Magdalena Regel-Rosocka and Maciej Wisniewski \\ Poznan University of Technology, Institute of Chemical Engineering and Technology \\ Poland
}

\section{Introduction}

In 1992 the information on the first, stable in water and air, room temperature ionic liquid was published. Since then the number of publications about ionic liquids (ILs) has been rapidly growing. Only in the year 2005 alone more than one thousand articles concerning ILs' synthesis, analysis and applications appeared. Various fields of ILs application are presented in Figure 1.

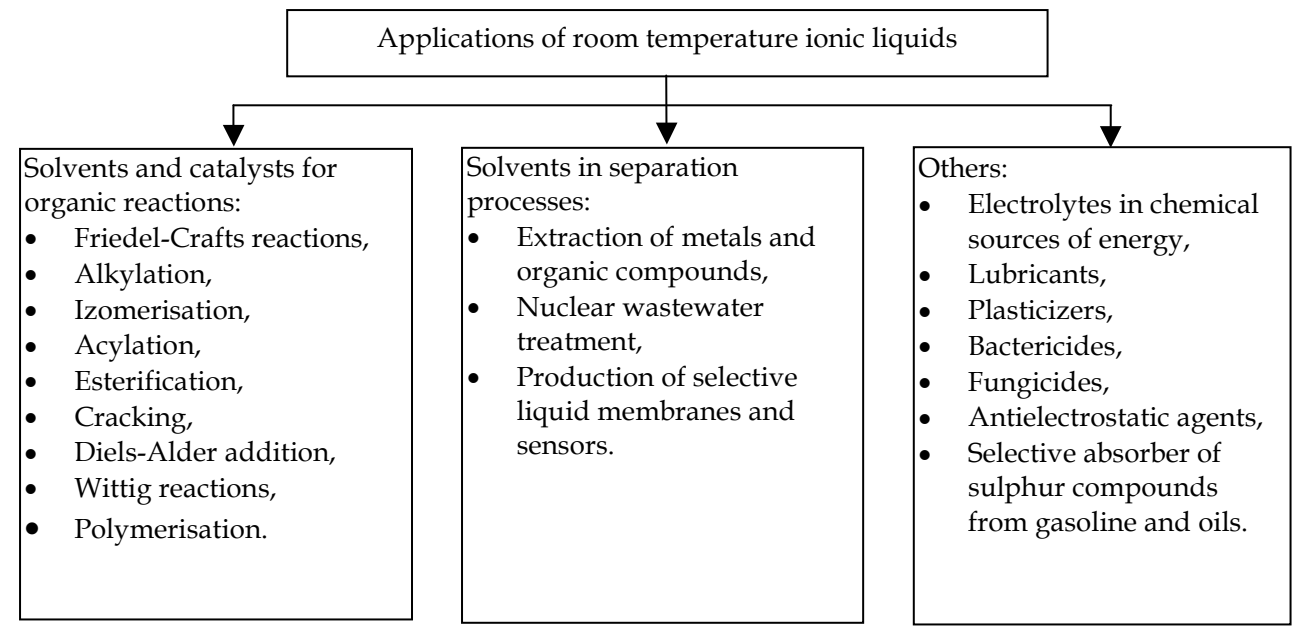

Fig. 1. Scheme of ILs' applications (Adams, 2002; Holbrey \& Seddon, 1999; Kosmulski et al., 2002; Pernak, 2003; Seddon et al., 2000).

Ionic liquids (ILs) have become widely used as solvents for organic reactions; however, recently they are more frequently used for separation of metal ions both in extraction, membrane and adsorption systems. In this paper their current applications as solvents and carriers in liquid-liquid extraction of metal ions are discussed and possible extraction mechanisms in ILs are considered in the light of their further use and prospective development. 


\section{General information on ILs}

ILs are salts that exist in liquid form at temperatures below $100^{\circ} \mathrm{C}$ (Holbrey \& Rogers, 2002) and their molecules are composed of a large asymmetric cation, e.g., 1-alkyl-3methylimidazolium, $\mathrm{N}$-alkylpyridinium, and an organic or inorganic anion. The most common cations and anions used for ILs synthesis are presented in Table 1. Depending on the cation and anion used, the properties of IL such as viscosity, cloud point and solubility in water can vary. The hydrophobicity of IL is determined by the anion. Most of the ionic liquids containing chloride anions are miscible with water, while those composed of $\left[\mathrm{PF}_{6}{ }^{-}\right]$ or $\left[\mathrm{Tf}_{2} \mathrm{~N}-\right]$ are very hydrophobic. A great advantage of ILs is the facility of anion replacement that enables designing compounds with properties required for particular application. These tuned salts are called task specific ionic liquids (TSIL). Moreover, their nonmeasurable volatility, non-flammability and thermal stability even up to $350^{\circ} \mathrm{C}$ make them very attractive for industrial use. They are expected to replace volatile organic compounds (especially halogenated organic solvents) in some systems and applications.

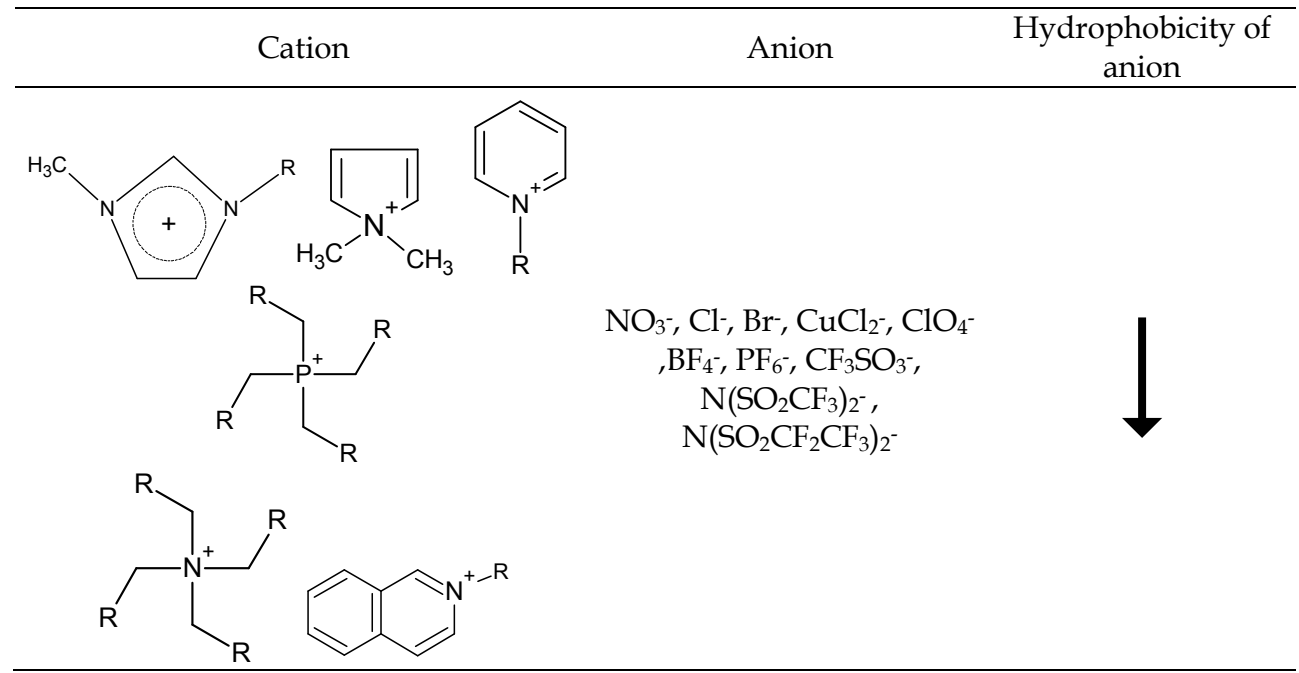

Table 1. Composition of ILs (Bradaric et al., 2003a, 2003b; Cocalia et al., 2005a; Del Sesto et al., 2005; Han \& Armstrong, 2007; Holbrey \& Rogers, 2002; Hunddleston et al., 1998; Pernak et al., 2005; Visser et al., 2001a; Visser et al., 2002a; Visser et al., 2003).

The wide range of their applications includes also those in extraction processes. Imidazolium ILs are solvents of main interest and have been comprehensively described. They are well defined and their synthesis is well established. Although they are employed in several extraction systems, only a few of them with successful and efficient stripping are described. Stripping from loaded organic phase containing IL is difficult because of strong interactions among ions.

Some ammonium and phosphonium ILs have been also applied in extraction processes, and are considered as prospective solvents and carriers in separation techniques (Bradaric et al., 2003a, 2003b; Del Sesto et al., 2005; Pernak et al., 2005). 


\section{Liquid-liquid extraction}

\subsection{Imidazolium ILs}

\subsubsection{Extraction systems}

Ionic liquids have become widely used as solvents for organic reactions, however their use as solvents in extraction systems seems much promising. Separation with imidazolium ILs is best described and broadly investigated. In most cases ILs replace typical solvent extraction diluents. The most frequently applied are 1-alkyl-3-methylimidazolium hexafluorophosphate $\left[\mathrm{C}_{\mathrm{n}} \mathrm{mim}\right]\left[\mathrm{PF}_{6}\right]$, tetrafluoroborate $\left[\mathrm{C}_{\mathrm{n}} \mathrm{mim}\right]\left[\mathrm{BF}_{4}\right]$ and bis(trifluoromethylsulphonyl)imide $\left[\mathrm{C}_{\mathrm{n}} \mathrm{mim}\right]\left[\mathrm{N}\left(\mathrm{SO}_{2} \mathrm{CF}_{3}\right)_{2}\right]$ (anion also abbreviated as $\left[\mathrm{Tf}_{2} \mathrm{~N}\right]$ ) (Table 2).

As shown in Table 2, alkali metals, $\mathrm{UO}_{2}{ }^{2+}, \mathrm{Cs}^{+}, \mathrm{Sr}^{2+}$ and lanthanides are most frequently extracted with imidazolium ILs. In most cases, extraction of metal ions into the hydrophobic ionic liquid phase is insignificant because metal cations are strongly hydrated in the aqueous phase and affinity of the IL phase to the aqueous one is too small. Thus, an extractant or ligand must be applied, which is a substance that, when diluted in IL, forms complexes with metal ions increasing their hydrophobicity and facilitating their transport to the IL phase. Examples of such ligands are the following macrocyclic compounds: pyridinecalix-4-arene, 18-crown-6 ether (18C6) or dicyclohexano-18-crown-6 (DCH18C6), industrial extractants - TBP (tributyl phosphate), CMPO (octyl(phenyl)-N,Ndiisobutylcarbamoylmethylphosphine oxide), PAN (1-(2-pyridylazo)-2-naphthol), TAN (1(2-thiazolyl)-2-naphthol) or neutral - TODGA ( $\mathrm{N}, \mathrm{N}, \mathrm{N}^{\prime}, \mathrm{N}^{\prime}$-tetra(octyl)diglycolamide) or DEHEHP (di(2-ethylhexyl)2-ethylhexyl phosphonate) (Table 2). Significant improvement in extraction efficiency of metal cations has been achieved when $\left[\mathrm{C}_{n} \mathrm{mim}\right]\left[\mathrm{Tf}_{2} \mathrm{~N}\right]$ replaces molecular solvents, such as chloroform, dodecane or 1-octanol, in pyridinecalix-4-arene (extraction of $\mathrm{Ag}^{+}$) (Shimojo \& Goto, 2004), in CMPO - extraction of $\mathrm{Ce}^{3+}, \mathrm{Eu}^{3+}, \mathrm{Y}^{3+}$ (Nakashima et al., 2003, 2005) - in PAN and TAN (extraction of $\mathrm{Hg}^{2+}$ ) (Visser et al., 2001b) by $\left[\mathrm{C}_{\mathrm{n}} \mathrm{mim}\right]\left[\mathrm{PF}_{6}\right]$, and in crown ethers $18 \mathrm{C} 6$ and DCH18C6 (extraction of alkali metals and $\mathrm{Sr}^{2+}$ ) (Dai et al., 1999; Dietz \& Stepinski, 2005; Jensen et al., 2002; Luo et al., 2004a; Stepinski et al., 2005). However, not always the presence of ILs in the organic phase instead of conventional solvents increases the partitioning of the species to be extracted. For example, uranium extraction into dodecane is more efficient than into $\left[\mathrm{C}_{n} \mathrm{mim}\right]\left[\mathrm{Tf}_{2} \mathrm{~N}\right]$ (Dietz \& Stepinski, 2008).

It is reported that $\mathrm{Cs}^{+}$extraction with crown ethers or calixarene tends to increase with shortening of the alkyl chain in IL cation (Luo et al., 2004b). However, a compromise should be made between the extraction efficiency and the solubility of ligand in IL. In other words, the shorter the alkyl chain the lower the solubility of a hydrophobic calixarene in the IL phase.

Furthermore, sodium extraction with DCH18C6 increases in the presence of $\left[\mathrm{C}_{n} \operatorname{mim}\right]\left[\mathrm{Tf}_{2} \mathrm{~N}\right]$ compared with 1-octanol (Table 3). However, it is noted that the partitioning of $\mathrm{Na}^{+}$is strongly affected by stereochemistry of the crown ether applied, which was not observed in conventional solvents (Dietz et al., 2008). In general, the mechanism of extraction can be tuned by changing the isomeric form of the extractant. The presence of trans isomers of DCH18C6 make the neutral complex extraction dominate over the ion-exchange mechanism. This mechanism is more environmentally friendly because of no release of IL to the aqueous phase.

Papaiconomou et al. (2008) investigated extraction of $\mathrm{Cu}^{2+}, \mathrm{Hg}^{2+}, \mathrm{Ag}^{+}$and $\mathrm{Pd}^{2+}$ from aqueous chloride solutions at $\mathrm{pH} 7$ with ten imidazolium, pyridinium, piperidinium and pyrrolidinium ionic liquids comprising typical anions, i.e., $\left[\mathrm{BF}_{4}^{-}\right],\left[\mathrm{Tf}_{2} \mathrm{~N}-\right]$, trifluoromethyl 


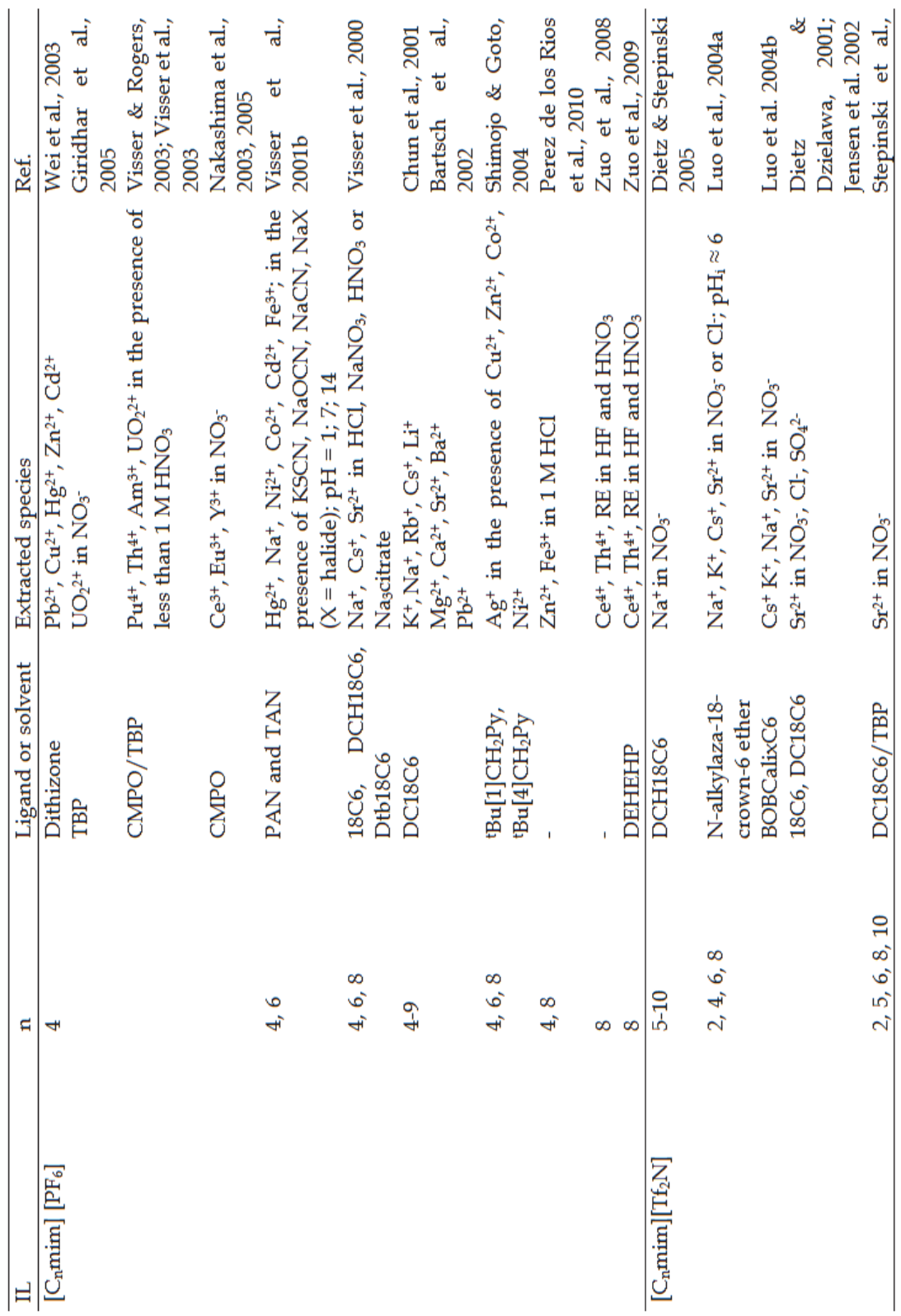




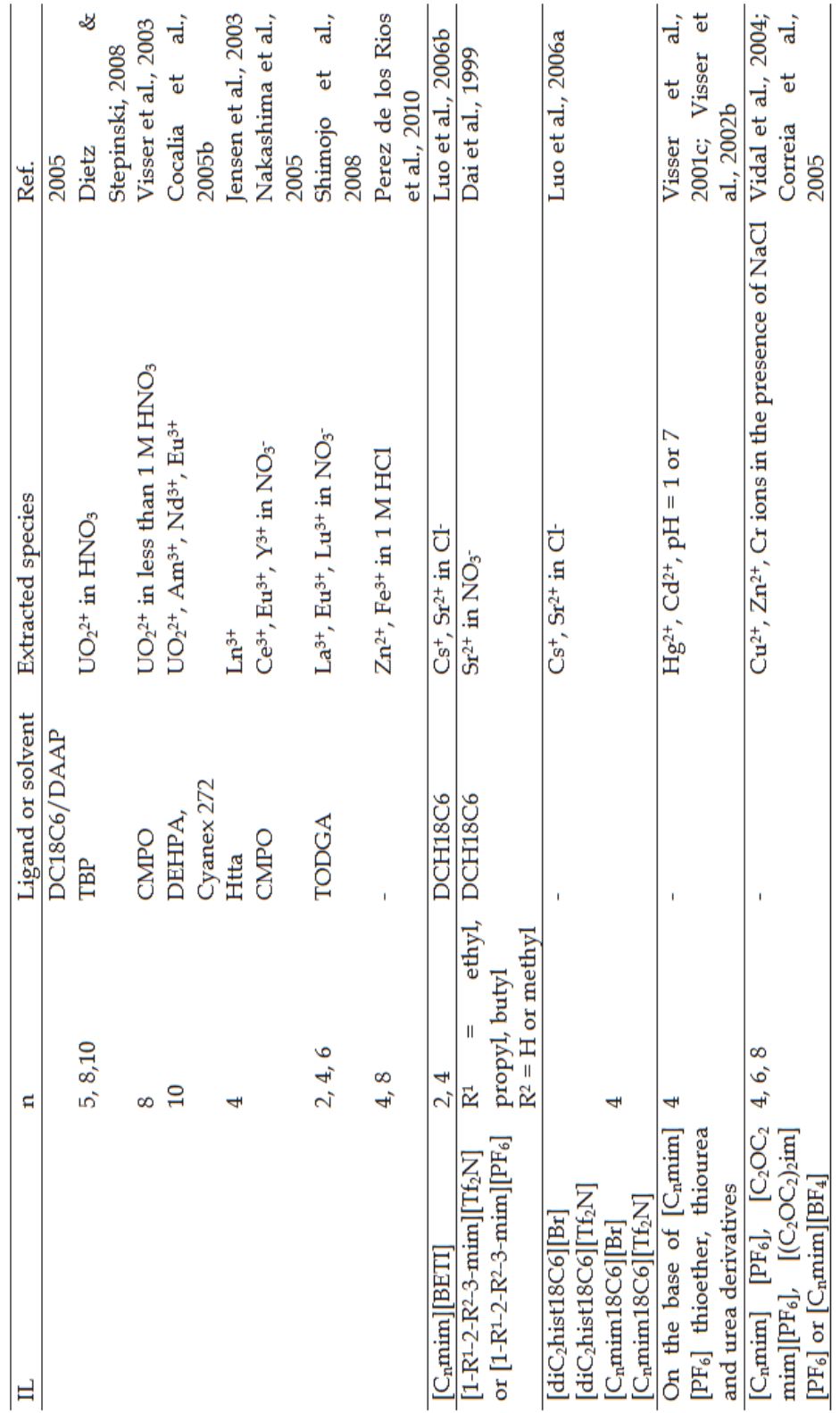

BOBCalixC6 calix[4]arene-bis(tert-octylbenzo-crown-6); Htta (1-(2-thienyl)-4,4,4-trifluoro-1,3butanedione); BETI bis(perfluoroethanesulphonyl)imide; $\left[\mathrm{C}_{2} \mathrm{OC}_{2} \mathrm{mim}\right]$ 1-(2-ethoxyethyl)-3methylimidazolium; [( $\left.\left.\mathrm{C}_{2} \mathrm{OC}_{2}\right) 2 \mathrm{im}\right]$ 1,3-bis(2-ethoxyethyl)imidazolium; [ $\mathrm{diC}_{2}$ hist18C6] N-(N,N-diethyl)histamonium aza-18-crown-6 ether; [ $\mathrm{C}_{4}$ mim18C6] N-(3-butylimidazolium propyl)aza-18-crown-6 ether Table 2. Imidazolium ionic liquids in selected extraction systems. 
sulphonate [TfO-] or nonafluorobutyl sulphonate [NfO-]. Only mercury has been efficiently extracted $(\mathrm{D}>24)$ with imidazolium and pyridinium ionic liquids, while the other metal cations are not transferred to the IL phase.

Moreover, good extraction abilities of imidazolium ILs with [NfO-] have been confirmed in the studies on $\mathrm{Li}^{+}, \mathrm{Na}^{+}, \mathrm{Cs}^{+}, \mathrm{Ca}^{2+}, \mathrm{Sr}^{2+}$ and $\mathrm{La}^{3+}$ extraction (Kozonoi \& Ikeda, 2007). According to the authors the metal ions with greater charge are more easily transferred to the $\left[\mathrm{C}_{\mathrm{n}} \mathrm{mim}\right][\mathrm{NfO}]$ phase.

Another point of view is represented by Wei et al. $(2003 a, 2003 b)$ and Domanska \& Rekawek (2009). They propose to complex metal ions in the aqueous phase with dithizone, 8hydroxyquinoline or 1-(2-pyridylazo)-2-naphthol and next, to extract such metal complexes with imidazolium ILs. The [ $\mathrm{C}_{\mathrm{n}}$ eim] ILs (Domanska \& Rekawek, 2009) show better extraction efficiency of $\mathrm{Ag}^{+}$and $\mathrm{Pb}^{2+}$ than chloroform, however, it decreases with increasing alkyl chain length in the cation and with increasing hydrophobicity of an anion (i.e., [ $\mathrm{Tf}_{2} \mathrm{~N}-$, $\left[\mathrm{PF}_{6}\right]$ ). The extraction with $\left[\mathrm{C}_{4} \mathrm{mim}\right]\left[\mathrm{PF}_{6}\right]$ (Wei et al. 2003a, 2003b) of various metal ions (e.g., $\mathrm{Ag}^{+}, \mathrm{Cu}^{2+}, \mathrm{Pb}^{2+}, \mathrm{Cd}^{2+}$ and $\left.\mathrm{Zn}^{2+}\right)$ is strongly dependent on $\mathrm{pH}$ and allows selective separation of $\mathrm{Cu}^{2+}$ from $\mathrm{Pb}^{2+}$ and $\mathrm{Zn}^{2+}$ at $\mathrm{pH} 2$ and from $\mathrm{Cd}^{2+}$ at $\mathrm{pH}$ 1.9. Furthermore, $\mathrm{Ag}^{+}$is selectively separated from $\mathrm{Pb}^{2+}$ also at $\mathrm{pH}$ 1.9. The dependence on $\mathrm{pH}$ is advantageous for stripping because metal ion can be stripped from the loaded IL phase by dissociation of metaldithizone complex with acid solution. $0.1 \mathrm{M} \mathrm{HNO}_{3}$ is used to regenerate IL and the reproducibility of extraction is confirmed in five cycles of recycling (extraction-stripping).

Not always an additional ligand is necessary to extract metal ions. For example, $\mathrm{Zn}^{2+}$ and $\mathrm{Fe}^{3+}$ can be transported directly to $\left[\mathrm{C}_{8} \mathrm{mim}\right]\left[\mathrm{BF}_{4}\right]$ phase. The extraction tends to increase in the following order: $\left[\mathrm{Tf}_{2} \mathrm{~N}^{-}\right]<\left[\mathrm{PF}_{6}\right]<\left[\mathrm{BF}_{4}^{-}\right]$that corresponds to decreasing hydrophobicity of the anions studied (Perez de los Rios et al., 2010). In parallel, the same authors observed increasing extraction efficiency with lengthening of the alkyl chain of imidazolium cation contrary to $\mathrm{Cs}^{+}$extraction studied by Luo et al. (2004b). Similarly, efficient extraction of $\mathrm{Ce}^{4^{+}}$ from $\mathrm{HNO}_{3}$ is shown in pure $\left[\mathrm{C}_{8} \mathrm{mim}\right]\left[\mathrm{PF}_{6}\right]$ (Zuo et al., 2008). However, its application for the recovery of $\mathrm{Ce}^{4+}$ from bastnasite leaching liquor, containing $\mathrm{Th}^{4+}$ and rare earth metals (RE), is limited by the presence of $\mathrm{F}^{-}$that negatively affects extraction efficiency. Because of this, neutral extractant (DEHEHP) has been added to $\left[\mathrm{C}_{8} \mathrm{mim}\right]\left[\mathrm{PF}_{6}\right]$ to overcome this problem and the extraction efficiency of metal ions is compared to that in the traditional DEHEHP-heptane system (Table 3) (Zuo et al., 2009). The selectivity of extraction in both IL and heptane systems can be ordered as follows: $\mathrm{Ce}^{4+}>\mathrm{Th}^{4+}>\mathrm{RE}^{3+}$.

The higher capacity for $\mathrm{Ce}^{4+}$ of DEHEHP-[C $\left.\mathrm{C}_{8} \mathrm{mim}\right] \mathrm{PF}_{6}$ than of DEHEHP-heptane indicates that both DEHEHP and $\left[\mathrm{C}_{8} \mathrm{mim}\right] \mathrm{PF}_{6}$ may act as extractants. The mechanism of extraction is presented in section 3.2.2.

Further, ILs dedicated to very specific extractions have been synthesized and called task specific ionic liquids (TSILs). Elimination of the use of additional extractant or ligand from the organic phase can be pointed out as a consequence of imidazolium cation modification with other compounds. However, according to Abbot et al. (2011), the term TSIL should be changed into 'functionalised ILs', as now most of ILs are designed and synthesised for a dedicated application.

N-(3-butylimidazolium propyl)aza-18-crown-6 ether bis[(trifluoromethyl)sulphonyl]imide $\left[\mathrm{C}_{4} \mathrm{mim} 18 \mathrm{C} 6\right]\left[\mathrm{Tf}_{2} \mathrm{~N}\right]$ illustrates TSIL with the IL-cation structure modified with aza-crown ether via covalent bonds (Luo et al., 2006a). Another type of TSIL, based on thioether, thiourea and urea derivatives, are involved as carriers in $\mathrm{Hg}^{2+}$ and $\mathrm{Cd}^{2+}$ liquid-liquid extraction (Visser et al., 2001c, 2002b). Correspondingly, ILs composed of a functional 


\begin{tabular}{|c|c|c|c|c|}
\hline IL system & $\mathrm{D}$ or $\mathrm{E}$ & $\begin{array}{l}\text { Conventional } \\
\text { solvent system }\end{array}$ & $\mathrm{D}$ & Ref. \\
\hline $\begin{array}{l}0.1 \mathrm{M} \text { in }\left[\mathrm{C}_{4} \mathrm{mim}\right]\left[\mathrm{Tf}_{2} \mathrm{~N}\right] \\
{\left[\mathrm{diC}_{2} \text { hist18C6][Tf } 2 \mathrm{~N}\right]} \\
{\left[\mathrm{C}_{4} \operatorname{mim} 18 \mathrm{C} 6\right]\left[\mathrm{Tf}_{2} \mathrm{~N}\right]}\end{array}$ & $\begin{array}{l}\mathrm{D}_{\mathrm{Cs}}=14.5 \\
\mathrm{D}_{\mathrm{Sr}}=447 \\
\mathrm{D}_{\mathrm{Cs}}=23.9 \\
\mathrm{D}_{\mathrm{Sr}}=213\end{array}$ & $\begin{array}{l}0.1 \mathrm{M} \text { in } \\
{\left[\mathrm{C}_{4} \mathrm{mim}\right]\left[\mathrm{Tf}_{2} \mathrm{~N}\right]} \\
\text { N-octylaza18C6 } \\
\text { DCH18C6 }\end{array}$ & $\begin{array}{l}\mathrm{Cs}^{+}=25.7 \\
\mathrm{D}_{\mathrm{Sr}}=1070 \\
\mathrm{Cs}^{+}=380 \\
\mathrm{D}_{\mathrm{Sr}}=935\end{array}$ & $\begin{array}{l}\text { Luo et al., } \\
\text { 2006a; Luo } \\
\text { et al., 2006b }\end{array}$ \\
\hline $\begin{array}{l}8 \mathrm{mM} \text { BOBCalixC6 in } \\
{\left[\mathrm{C}_{4} \mathrm{mim}\right]\left[\mathrm{Tf}_{2} \mathrm{~N}\right]}\end{array}$ & $\begin{array}{l}\mathrm{D}_{\mathrm{Cs}}=576 \\
\mathrm{D}_{\mathrm{K}}=8.4 \\
\mathrm{D}_{\mathrm{Sr}}=0\end{array}$ & $\begin{array}{l}0.01 \mathrm{M} \text { BOBCalixC6 } \\
\text { in 1,2-dichloroethane }\end{array}$ & $\begin{array}{l}\mathrm{D}_{\mathrm{Cs}} \\
\text { negligible }\end{array}$ & $\begin{array}{l}\text { Luo et al., } \\
\text { 2004b; } \\
\text { Haverlock } \\
\text { et al., } 2000\end{array}$ \\
\hline $\begin{array}{l}0.15 \mathrm{M} \text { DCH18C6 in } \\
{\left[\mathrm{C}_{2} \mathrm{mim}\right]\left[\mathrm{Tf}_{2} \mathrm{~N}\right]} \\
{\left[\mathrm{C}_{4} \mathrm{mim}\right]\left[\mathrm{PF}_{6}\right]}\end{array}$ & $\begin{array}{l}D_{S r}=1100 \\
D_{S r}=2.4\end{array}$ & $\begin{array}{l}0.15 \mathrm{M} \mathrm{DCH} 18 \mathrm{C} 6 \text { in } \\
\text { toluene } \\
\text { chloroform }\end{array}$ & $\begin{array}{l}D_{S r}=0.76 \\
D_{S r}=0.77\end{array}$ & $\begin{array}{l}\text { Dai et al., } \\
1999\end{array}$ \\
\hline $\begin{array}{l}0.1 \mathrm{M} \mathrm{DCH} 18 \mathrm{C} 6 \text { in } \\
{\left[\mathrm{C}_{5} \mathrm{mim}\right]\left[\mathrm{Tf}_{2} \mathrm{~N}\right]} \\
{\left[\mathrm{C}_{10} \mathrm{mim}\right]\left[\mathrm{Tf}_{2} \mathrm{~N}\right]} \\
\end{array}$ & $\begin{array}{l}\mathrm{D}_{\mathrm{Sr}} \sim 8 \\
\mathrm{D}_{\mathrm{Sr}} \sim 4 \\
\end{array}$ & $\begin{array}{l}0.1 \mathrm{M} \mathrm{DCH} 18 \mathrm{C} 6 \text { in } \\
\text { 1-octanol }\end{array}$ & $\mathrm{D}_{\mathrm{Sr}}=1$ & $\begin{array}{l}\text { Dietz et al., } \\
2003\end{array}$ \\
\hline $\begin{array}{l}0.1 \mathrm{M} \mathrm{DCH} 18 \mathrm{C} 6 \text { in } \\
{\left[\mathrm{C}_{5} \mathrm{mim}\right]\left[\mathrm{Tf}_{2} \mathrm{~N}\right]} \\
{\left[\mathrm{C}_{10} \mathrm{mim}\right]\left[\mathrm{Tf}_{2} \mathrm{~N}\right]}\end{array}$ & $\begin{array}{l}\text { in } 1 \mathrm{M} \\
\mathrm{HNO}_{3} \\
\mathrm{D}_{\mathrm{Na}} \sim 0.11 \\
\mathrm{D}_{\mathrm{Na}} \sim 0.1 \\
\end{array}$ & $\begin{array}{l}0.1 \mathrm{M} \mathrm{DCH} 18 \mathrm{C} 6 \text { in } \\
\text { 1-octanol }\end{array}$ & $\begin{array}{l}\text { in } 1 \mathrm{M} \\
\mathrm{HNO}_{3} \\
\mathrm{D}_{\mathrm{Na}} \sim 0.06\end{array}$ & $\begin{array}{l}\text { Dietz \& } \\
\text { Stepinski, } \\
2005\end{array}$ \\
\hline $\begin{array}{l}0.1 \mathrm{M} \mathrm{CMPO} \text { in } \\
{\left[\mathrm{C}_{4} \mathrm{mim}\right]\left[\mathrm{PF}_{6}\right]}\end{array}$ & $\mathrm{D}_{\mathrm{UO} 2}=1000$ & $\begin{array}{l}0.1 \mathrm{M} \text { CMPO in } \\
\text { dodecane }\end{array}$ & $\mathrm{DUO}_{2}=100$ & $\begin{array}{l}\text { Visser \& } \\
\text { Rogers, }\end{array}$ \\
\hline $\begin{array}{l}0.6 \mathrm{mM} \text { TODGA in } \\
{\left[\mathrm{C}_{2} \mathrm{mim}\right]\left[\mathrm{Tf}_{2} \mathrm{~N}\right]}\end{array}$ & $\mathrm{D}_{\mathrm{La}}=100$ & $\begin{array}{l}5 \mathrm{mM} \text { TODGA in } \\
\text { isooctane }\end{array}$ & $\mathrm{D}_{\mathrm{La}}=0.01$ & $\begin{array}{l}\text { Shimojo et } \\
\text { al., } 2008\end{array}$ \\
\hline $\begin{array}{l}0.34 \mathrm{M} \text { DEHEHP in } \\
{\left[\mathrm{C}_{8} \mathrm{mim}\right]\left[\mathrm{PF}_{6}\right]}\end{array}$ & $\begin{array}{l}\mathrm{E}_{\mathrm{Ce}(\mathrm{IV})}=99 \% \\
\mathrm{E}_{\mathrm{Ce}(\mathrm{III})}=2 \% \\
\mathrm{E}_{\mathrm{Th}}=49 \%\end{array}$ & $\begin{array}{l}0.34 \mathrm{M} \text { DEHEHP in } \\
\text { heptane }\end{array}$ & $\begin{array}{l}\mathrm{E}_{\mathrm{Ce}(\mathrm{IV})}=96 \% \\
\mathrm{E}_{\mathrm{Ce}(\mathrm{III})}=2 \% \\
\mathrm{E}_{\mathrm{Th}}=30 \%\end{array}$ & $\begin{array}{l}\text { Zuo et al., } \\
2009\end{array}$ \\
\hline
\end{tabular}

Table 3. Comparison of selected distribution coefficients of metal ions between IL or conventional solvent and the aqueous phase.

disulphide group bonded to piperidinium or pyrrolidinium cation show high selectivity toward $\mathrm{Hg}^{2+}$ or $\mathrm{Cu}^{2+}$ extraction. Moreover, ionic liquids containing a functional nitrile group bonded to pyridinium or piperidinium cation are found to extract completely $\mathrm{Ag}^{+}$and $\mathrm{Pd}^{2+}$ from the aqueous phase (Papaiconomou et al., 2008). It can be concluded that the type of functional group, cation ring and anion strongly influence the extraction abilities and selectivity.

Nevertheless, limited quantities of these tuned compounds should be emphasised as the main drawback of TSIL use for extraction. For this reason they could be applied for removal of metal ions in very low concentrations or immobilised at any support. Although metal ions can be stripped easily, it seems that aza-crown modified TSILs are less efficient in $\mathrm{Cs}^{+}$ and $\mathrm{Sr}^{2+}$ extraction than the IL phase mixed with DCH18C6 or N-octylaza 18C6 as extractants (Table 3). High $\mathrm{Cs}^{+}$extraction is observed for BOBCalixC6 in $\left[\mathrm{C}_{4} \mathrm{mim}\right]\left[\mathrm{Tf}_{2} \mathrm{~N}\right]$ (Luo et al., 2004b). What is important, the selectivity of $\mathrm{Cs}^{+}$extraction over $\mathrm{Na}^{+}$and $\mathrm{Sr}^{2+}$ is higher than in conventional organic solvents, while $\mathrm{Cs}^{+}$extraction over $\mathrm{K}^{+}$is lower in 
$\left[\mathrm{C}_{4} \mathrm{mim}\right]\left[\mathrm{Tf}_{2} \mathrm{~N}\right]$. The selectivity of $\mathrm{Sr}^{2+} / \mathrm{Cs}^{+}$can be tuned by the choice of IL anion. $\mathrm{Sr}^{2+}$ extraction prevails over that of $\mathrm{Cs}^{+}$with increasing anion hydrophobicity for $\left[\mathrm{C}_{4} \mathrm{mim}\right]$ cation (Luo et al., 2006b).

The synergism observed in the presence of ILs is attributed to ion-recognition capabilities of complexing ligands, unique ionic solvation environment and ion-exchange capabilities of ILs (Luo et al., 2006a).

\subsubsection{Mechanism of extraction}

The differences in extraction efficiency between IL and conventional solvent systems are significant, as presented in Table 3. Generally, in IL systems an increase in distribution ratios and selectivity is observed. It has been indicated that cation-exchange is a mechanism of extraction with imidazolium ILs (Table 4) and emphasized that a mechanism different from that in conventional solvents, affects the extraction efficiency. It can be attributed to a change in coordination environment of extracted species, in other words, to a change in the number of ligands coordinating with metal ions. An example is $\mathrm{La}^{3+}$ extraction with TODGA in isooctane and in $\left[\mathrm{C}_{2} \mathrm{mim}\right]\left[\mathrm{Tf}_{2} \mathrm{~N}\right]$ (Shimojo et al., 2008), in which a change in extraction mechanism from ion-pair extraction accompanied by anions (in isooctane) into cation-exchange (in IL) is observed (eq. 1). The same observations have been made by Shen et al. (2011) for $\mathrm{UO}_{2}{ }^{2+}$ extraction with other diglycolamides (TBDA - N,N,N', $\mathrm{N}^{\prime}$-tetrabutyl-3oxapentanediamide and MBDA - N,N, $\mathrm{N}^{\prime}, \mathrm{N}^{\prime}$-dimethyldibutyl-3-oxapentanediamide). It can be concluded that the change in extraction mechanism depends on the acid (in this case $\mathrm{HNO}_{3}$ ) concentration. At low acidity ion exchange is favoured, while at high acid content neutral uranyl-diamide nitrato complexes are extracted. For example, for $\mathrm{La}^{3+}$ extraction with $\left[\mathrm{C}_{\mathrm{n}} \mathrm{mim}\right][\mathrm{NfO}]$ (without additional ligands) cation exchange between two phases with the partial transfer of non-charged species has been proposed (Kozonoi \& Ikeda, 2007).

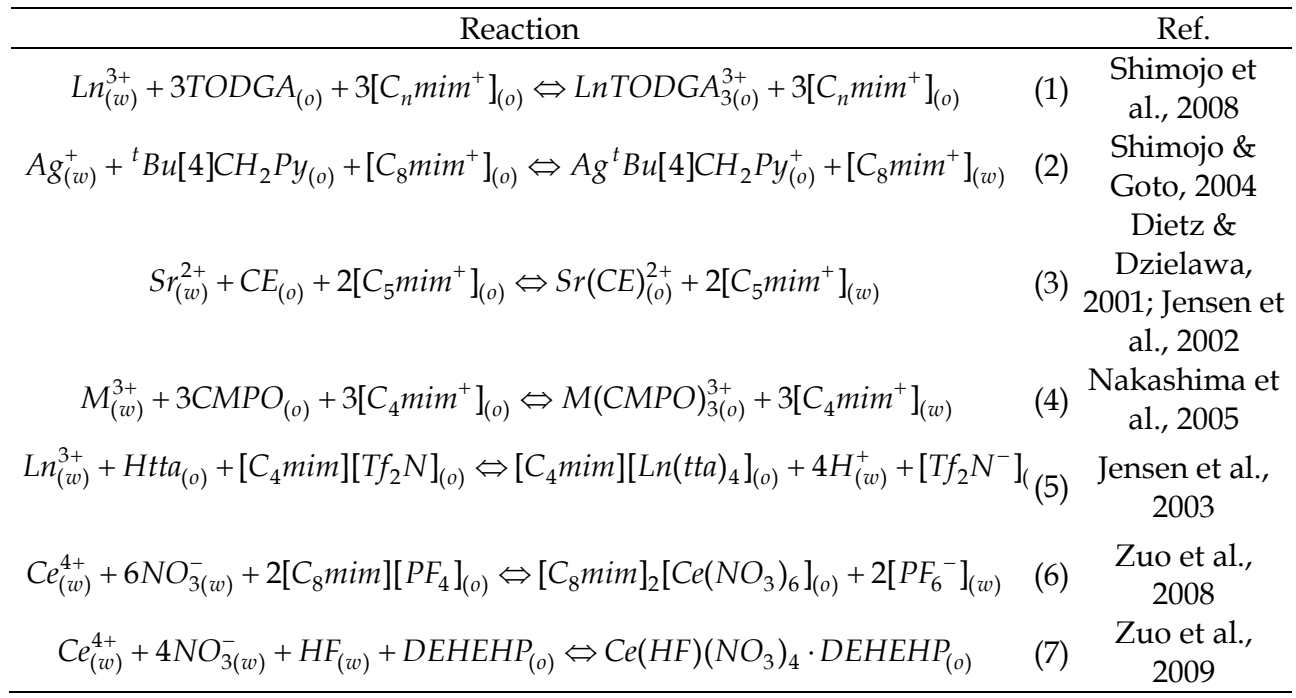

${ }^{\mathrm{t}} \mathrm{Bu}[4] \mathrm{CH}_{2} \mathrm{Py}$ - pyridinecalix-4-arene; $\mathrm{CE}$ - crown ether; $(\mathrm{w})$ and $(\mathrm{o})$ denote aqueous and organic phase.

Table 4. Reactions of metal cations with imidazolium Ils. 
Equations (2)-(4) can be combined into one equation of extraction according to cationexchange mechanism, where $\mathrm{L}$ is a ligand complexing metal cation in the organic phase:

$$
M_{(w)}^{m+}+m L_{(o)}+m\left[C_{n} m i m^{+}\right]_{(o)} \Leftrightarrow M L_{m(o)}^{m+}+m\left[C_{n} m^{2} m^{+}\right]_{(w)}
$$

Metal cation binds the ligand contained in the organic phase, and then it is exchanged for imidazolium cation $\left[\mathrm{C}_{\mathrm{n}} \mathrm{mim}^{+}\right]$of the ionic liquid. When metal cation becomes, as a result of extraction, a part of ionic liquid and is strongly bound in the organic phase, its stripping is very difficult. Additionally, the loss of IL cation to the aqueous phase is not advantageous for high cost and environmental impact (Dietz, 2006). However, the change in the $\mathrm{Sr}^{2+}$ and $\mathrm{Cs}^{+}$extraction mechanism from cation-exchange to extraction of neutral complexes, observed with increasing alkyl chain in imidazolium cation (Dietz et al., 2003), causes a reduction in IL loss to the aqueous phase. Alternatively, to overcome the loss of IL cation Luo et al. (2004b) have proposed addition of organophilic species $\left(\mathrm{NaBPh}_{4}\right)$ to control a transfer of imidazolium cations to the aqueous phase. Its addition decreases the loss of IL cation by $24 \%$.

The knowledge of extraction mechanism with participation of ILs has been continuously extended. Recently, Dietz \& Stepinski (2005) have reported a complex extraction process of $\mathrm{Na}^{+}$from nitrate solution with crown ether in $\left[\mathrm{C}_{\mathrm{n}} \mathrm{mim}\right]\left[\mathrm{Tf}_{2} \mathrm{~N}\right]$, described by a combination of three processes:

- sodium nitrato-crown ether complex partitioning:

$$
\mathrm{Na} \cdot \mathrm{DCH} 18 \mathrm{C6}^{+}+\mathrm{NO}_{3}^{-} \rightarrow\left(\mathrm{NaNO}_{3} \cdot \mathrm{DCH} 18 \mathrm{C} 6\right)_{(0)}
$$

- $\quad$ exchange of the 1:1 sodium-crown ether complex for the IL cation:

$$
\mathrm{Na} \cdot \mathrm{DCH} 18 \mathrm{C6} 6^{+}+\left[\mathrm{C}_{n} \operatorname{mim}\right]\left[\mathrm{Tf}_{2} \mathrm{~N}\right]_{(o)} \rightarrow[\mathrm{NaDCH} 18 \mathrm{C} 6]\left[\mathrm{Tf}_{2} \mathrm{~N}\right]_{(o)}+\mathrm{C}_{n} \operatorname{mim}_{(w)}^{+}
$$

- crown ether mediated $\mathrm{Na}^{+} / \mathrm{H}_{2} \mathrm{O}$ exchange at high acidity:

$$
\mathrm{Na}^{+}+\left(\mathrm{H}_{3} \mathrm{O} \cdot \mathrm{DCH} 18 \mathrm{C} 6^{+}\right)_{(o)} \rightarrow\left(\mathrm{Na} \cdot \mathrm{DCH} 18 \mathrm{C} 6^{+}\right)_{(o)}+\mathrm{H}_{3} \mathrm{O}^{+}
$$

This complex three-path-mechanism opens the opportunities to design IL based extraction systems to improve selectivity of conventional organic phases.

Recycling of the crown ether-IL phase loaded with metal ions can proceed by simple $\mathrm{pH}$ change. For example, at low $\mathrm{pH}$ protonated aza crown releases $98 \% \mathrm{Cs}^{+}$and $\mathrm{Sr}^{2+}$, and can be reused for extraction after deprotonation with base (Luo et al., 2004a).

In contrast, the anion exchange mechanism is proposed for lanthanide extraction $\left(\operatorname{Ln}^{3+}\right)$ in the system with $\mathrm{Htta}$ in $\left[\mathrm{C}_{4} \mathrm{mim}\right]\left[\mathrm{Tf}_{2} \mathrm{~N}\right]$ (Jensen et al., 2003). As a result of complex $\mathrm{Ln}(\mathrm{tta})_{4^{-}}$ formation in the organic phase, four protons are released, and simultaneously $\left[\mathrm{Tf}_{2} \mathrm{~N}-\right]$ anion is transferred to the aqueous phase according to reaction (5) presented in Table 4. A similar extraction mechanism is proposed for pure $\left[\mathrm{C}_{8} \mathrm{mim}\right]\left[\mathrm{PF}_{6}\right]$, while with DEHEHP in $\left[\mathrm{C}_{8} \mathrm{mim}\right]\left[\mathrm{PF}_{6}\right]$ the neutral complexing extraction mechanism, eq. (7), is proposed (Zuo et al., 2008,2009 ). The latter mechanism seems to be more advantageous as no IL is lost to the aqueous phase.

As a result, stripping in these systems is easier than for the cation-exchange mechanism, because it is enough to use an aqueous solution of $\mathrm{H}\left(\mathrm{Tf}_{2} \mathrm{~N}\right)$ or $\mathrm{KPF}_{6}$ to reverse the 
equilibrium of reactions (5-7). At the same time pure cerium as $\mathrm{CeF}_{3}$ nano-particles or $\mathrm{Ce}_{2}\left(\mathrm{SO}_{4}\right)_{3}$ solutions are obtained as products after regeneration of the $\left[\mathrm{C}_{8} \mathrm{mim}\right]\left[\mathrm{PF}_{6}\right]$ phase. However, it is proven by Rickert et al. (2007) that the presence of certain solutes (e.g., crown ethers) in a hydrophobic IL, even in the absence of metal ion in the extraction system, can significantly increase the solubility of the ionic liquid in acidic aqueous media. Thus, it is still an open question whether they are environmentally friendly and can replace traditional organic solvents.

Apart from small amounts of synthesised ILs and their solubility in the aqueous phase, there is one more issue that must be indicated as limiting the ILs use for liquid-liquid extraction, which is their hydrolysis in the contact with an acidic solution (Swatloski et al., 2003). It is particularly risky to use $\left[\mathrm{PF}_{6}\right]$ containing ILs because the decomposition reaction of the anion leads to a toxic and corrosive product HF. Additionally, during acidic reactions gas HF may be released. Thus, Swatloski et al. (2003) propose to consider the list of non-toxic pharmaceutically acceptable anions when designing ILs as solvents for extraction.

\subsection{Ammonium ILs}

\subsubsection{Extraction systems}

Some ionic liquid extraction systems operate very efficiently without a ligand complexing metal ions. An example of such liquids is methyltrioctylammonium salt (Aliquat 336), a reagent used for extraction for many years.

Several Aliquat 336 [A336] derived ILs have been already described in literature. Some of them can be applied for separation of metal ions; however, methyltrioctylammonium thiosalicylate [A336][TS] seems to be the most efficient among those studied.

Extraction of $\mathrm{Pd}^{2+}$ with [A336][Cl] and [A336][NO $\left.\mathrm{NO}_{3}\right]$ is efficient, however, [A336][Cl] provides stronger binding abilities (Giridhar et al., 2006). Direct electrodeposition is proposed as an interesting and effective method of metal recovery from the IL phase due to the wide electrochemical window of ILs and their ion exchange abilities.

[A336][TS], thiocyanate [SCN] and methionate [Met] are used for preconcentration of $\mathrm{UO}_{2}{ }^{2+}$ (Srncik et al., 2009) and [A336][TS], benzoate [BA] and hexanoate [Hex] for removal of cadmium(II) from natural river matrix (Kogelnig et al., 2008) by extraction. The extraction efficiency from river water decreases in the following order of ILs used: [A336][TS] (>99.9\%) $>$ [A336][Hex] $(14 \%)>$ [A336][BA] $(11 \%)$. It is suggested that the application of [A336][TS] may be considered as more sustainable than that of systems with volatile solvents because the risk related to volatile and flammable solvents is eliminated. Pure [A336][Cl] allows almost complete removal of $\mathrm{Zn}^{2+}$ and $\mathrm{Fe}^{3+}$ from $1 \mathrm{M} \mathrm{HCl}$ (Perez de los Rios et al., 2010), which is in agreement with numerous previous studies on [A336][Cl] solutions in typical VOCs (Kejun et al., 2004; Sato et al., 2010; Wionczyk, 2009).

Aliquat 336 and quaternary phosphonium cation [QP] with 2-(methylthio)benzoate [MTBA] and [TS] have been applied as extracting agents for $\mathrm{Pt}^{4+}$ from chloride solution. The extraction efficiency tends to diminish with decreasing viscosity of IL in the following order: [QP][MTBA] $(100 \%)>$ [A336][TS] $(85 \%)>$ [QP][TS] $(76 \%)>$ [A336][MTBA] $(40 \%)$ (Stojanovic et al., 2010). Thus, it proves that not only 'functionality appended' to the anion but also physico-chemical properties of IL play an important role in extraction of metal ions.

\subsubsection{Mechanism of extraction}

Egorov et al. (2010) have used methyltrioctylammonium salicylate [A336][Sal] for extraction of $\mathrm{Fe}^{3+}, \mathrm{Cu}^{2+}, \mathrm{Ni}^{2+}, \mathrm{Mn}^{2+}$ from various solutions of their salts: sulphate, nitrate, chloride, 
chloride, respectively. [A336][Sal] efficiently extracts $\mathrm{Fe}^{3+}$ and $\mathrm{Cu}^{2+}$ (99 and 89\%). The mechanism proposed for the extraction of $\mathrm{Fe}^{3+}$ may be represented by equation (12) given in Table 5.

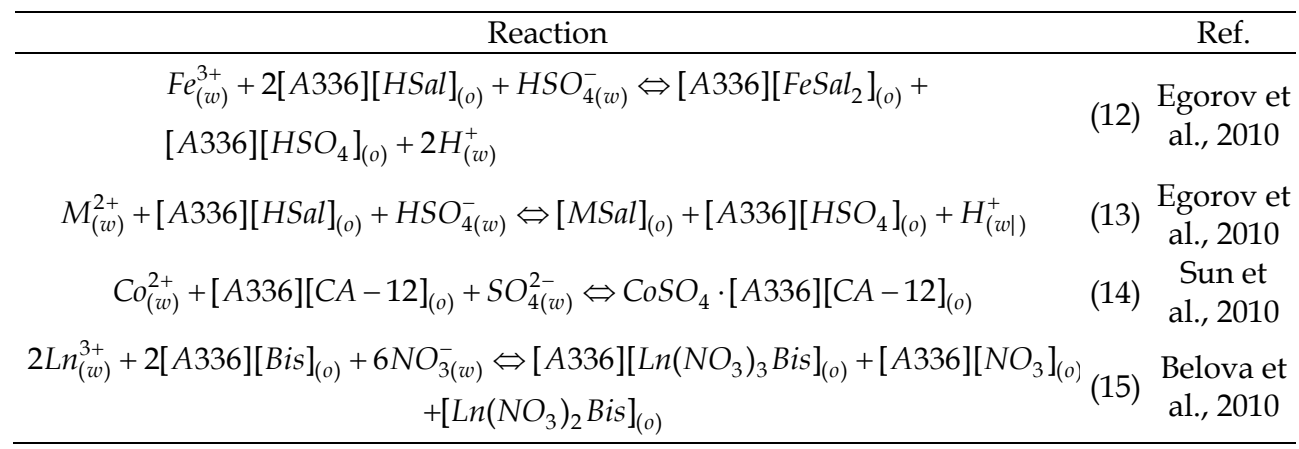

Table 5. Reactions of metal ions with ammonium Ils.

For divalent metals $\left(\mathrm{M}^{2+}\right)$ the mechanism is similar, however, in this case a formation of metal ion salicylate in the organic phase is expected (Table 5, eq. (13)). In each reaction, protons are released to the aqueous phase while no transfer of IL is observed. Separation factors of $\mathrm{Fe}^{3+}$ over other metals such as $\mathrm{Co}^{2+}, \mathrm{Ni}^{2+}, \mathrm{Mn}^{2+}, \mathrm{Cr}^{3+}$ and $\mathrm{Zn}^{2+}$ are high and in all cases exceed 10. It means that $\mathrm{Fe}^{3+}$ can be selectively separated from such solutions.

$0.02 \mathrm{M}$ [A336][CA-12] (sec-octylphenoxy acetate) mixed with toluene has been studied for $\mathrm{Co}^{2+}$ and $\mathrm{Ni}^{2+}$ separation from sulphate solutions (Sun et al., 2010). The inner synergistic effect, defined as synergistic effect coming from cation and anion of a bifunctional IL [A336][CA-12] is observed, and the ion association mechanism (Table 5, eq. (14)) is proposed for the reaction of $\mathrm{Co}^{2+}$ extraction from sulphate liquor. Easy stripping with diluted $\mathrm{H}_{2} \mathrm{SO}_{4}$ may confirm rather weak binding of $\mathrm{Co}^{2+}$ in this IL phase.

Again methyltrioctylammonium based IL is proposed for $\mathrm{La}^{3+}$ and $\mathrm{Y}^{3+}$ extraction from nitric acid solution (Belova et al., 2010). After analysis of extraction constants for various extraction reactions of [A336][Bis] (bis(2,4,4-trimethylpentyl)phosphinate) and lanthanides $\left(\mathrm{Ln}^{3+}\right)$, these authors have suggested that several species are formed in the organic phase according to eq. (15) (Table 5). The ratio between them depends on their stability and is difficult to evaluate.

\subsection{Phosphonium ILs}

Besides imidazolium and ammonium ILs, also phosphonium ionic liquids are considered to be prospective for substance separation (Bradaric et al., 2003b), and have been proposed as solvents for crown ether extractants mixed with organic solvents and as carriers in impregnated resins (Campos et al., 2008a, 2008b; Gallardo et al., 2008; Guibal et al., 2008).

In fact, many phosphonium ILs used for separation are based on widely known and applied Cytec Industries extractants such as trialkylphosphine oxides or Cyanex 272; however there is still little information about their use in extraction processes. Some commercial phosphonium ionic liquids (Cyphos series) studied in separation processes are presented in Table 6. 
<smiles>ClP(c1ccccc1)(c1ccccc1)(c1ccccc1)c1ccccc1</smiles>

Cyphos IL 101, Trihexyl(tetradecyl)phosphonium chloride [QP][Cl]<smiles>O=S(=O)(NS(=O)(=O)C(F)(F)F)c1ccccc1</smiles>

Cyphos IL 109, Trihexyl(tetradecyl)phosphonium bis(trifluoromethylsulphonyl)imide $[\mathrm{QP}]\left[\mathrm{Tf}_{2} \mathrm{~N}\right]$<smiles>CC(CC(C)CC(C)(C)CC(C)(C)CC(C)(C)C)CC(C)(C)C</smiles>

Cyphos IL 104,

Trihexyl(tetradecyl)phosphonium bis(2,4,4trimethylpentyl)phosphinate [QP][Bis]<smiles>CCCCCCCC(C)(C)P</smiles>

Cyphos IL 111, Trihexyl(tetradecyl)phosphonium tetrafluoroborate

[QP] $\left[\mathrm{BF}_{4}\right]$

Table 6. Structures of exemplary phosphonium ILs used in extraction systems.

Turanov et al. (2008) have studied partitioning of lanthanide chlorides between $\mathrm{HCl}$ and organic solutions of neutral organophosphorous compounds and IL - e.g., butyldiphenylphosphonium hexafluorophosphate and bis(trifluoromethylsulphonyl)imide. However, the presence of phosphonium ILs does not affect lanthanide extraction as strongly as imidazolium ILs, i.e., $\left[\mathrm{C}_{4} \mathrm{mim}\right]\left[\mathrm{PF}_{6}\right]$ and $\left[\mathrm{C}_{4} \mathrm{mim}\right]\left[\mathrm{Tf}_{2} \mathrm{~N}\right]$.

Efficient extraction of $\mathrm{Fe}^{3+}$ from $6 \mathrm{M} \mathrm{HCl}$ with [QP][Cl] dissolved in chloroform is reported by Kogelnig et al. (2010). At the same time $\mathrm{Ni}^{2+}$ is not extracted which enabled $\mathrm{Fe}^{3+}$ to be separated from the other metal ions. The spectroscopic data support the assumption that tetrachloroferrate is formed in the organic phase according to the equation (16) (Table 7).

\begin{tabular}{ccc}
\hline Reaction & Ref. \\
\hline $\mathrm{FeCl}_{4(w)}^{-}+[Q P][\mathrm{Cl}]_{(o)} \Leftrightarrow[\mathrm{QP}][\mathrm{FeCl}]_{(o)}+\mathrm{Cl}_{(w)}^{-}$ & (16) $\begin{array}{c}\text { Kogelnig et } \\
\text { al., } 2010 \\
\mathrm{Na}_{(w)}^{+}+\mathrm{TcO}_{4(w)}^{-}+C E_{(o)} \Leftrightarrow \mathrm{Na} \cdot \mathrm{CE}^{+} \mathrm{TcO}_{4(o)}^{-}\end{array}$ & (17) $\begin{array}{c}\text { Stepinski et } \\
\text { al., 2010 }\end{array}$ \\
\hline
\end{tabular}

Table 7. Reactions of metal ions with phosphonium Ils.

Recently, phosphonium ILs have been reported as solvents for DCH18C6 to extract $\mathrm{TcO}_{4}{ }^{-}$ and $\mathrm{ReO}_{4}^{-}$from $\mathrm{NaOH}$ and/or $\mathrm{NH}_{4} \mathrm{OH}$ solutions (Stepinski et al., 2010). The use of $[\mathrm{QP}]\left[\mathrm{Tf}_{2} \mathrm{~N}\right]$ ensures the highest distribution of $\mathrm{TcO}_{4}{ }^{-}$both in the presence and absence of a crown ether and prefers extraction of $\mathrm{TcO}_{4}^{-}$over $\mathrm{ReO}_{4^{-}}$. The most important is that, unlike imidazolium ILs, [QP] $\left.\mathrm{Tf}_{2} \mathrm{~N}\right]$ extracts without IL loss (negligible amounts of $\left[\mathrm{Tf}_{2} \mathrm{~N}^{-}\right]$ 
determined) to the aqueous phase. Owing to this, it has been suggested by Stepinski et al. that 'these solvents may provide the basis for improved approaches to the extraction and recovery of a variety of anions'. The dominant extraction mechanism is the ion pair transfer according to eq. (17) included in Table 7. The enhancement in $\mathrm{TcO}_{4}^{-}$extraction with crown ether, compared with conventional solvents, is attributed to improvement in the solvation properties of IL.

The authors of the chapter have studied Cyphos ILs as extractants for regeneration of spent pickling solutions from hot-dip galvanizing plants (Marszalkowska et al., 2010; Nowak et al., 2010; Regel-Rosocka et al. 2006, 2007; Regel-Rosocka, 2009, 2010).

Among the studied extractants trihexyl(tetradecyl)phosphonium chloride (Cyphos IL 101), trihexyl(tetradecyl)phosphonium bis(2,4,4-trimethylpentyl)phosphinate (Cyphos IL 104), trihexyl(tetradecyl)phosphonium bis(trifluoromethylsulphonyl)imide (Cyphos IL 109), and trihexyl(tetradecyl)phosphonium tetrafluoroborate (Cyphos IL 111) in mixture with toluene have been investigated as reagents to extract $\mathrm{Zn}^{2+}, \mathrm{Fe}^{3+}$ or $\mathrm{Fe}^{2+}$ from chloride media. Toluene has been applied to overcome some drawbacks caused by the high viscosity of ILs. In some cases alkylene carbonates (propylene or butylene carbonate) as novel diluents in extraction of $\mathrm{Zn}^{2+}$ and $\mathrm{Fe}^{3+}$ have been used replacing toluene. In addition, TBP has been used to modify the organic phase properties.

\subsubsection{Extraction of $\mathrm{Zn}^{2+}$}

The removal of toxic $\mathrm{Zn}^{2+}$ is an important issue in the area of disposal of spent pickling solutions (SPS) from hot-dip galvanizing plants. As a result of pickling, $\mathrm{Zn}^{2+}$ concentration in spent solutions increases even up to $130 \mathrm{~g} / \mathrm{dm}^{3}$, iron content to $100 \mathrm{~g} / \mathrm{dm}^{3}, \mathrm{HCl}$ to $10 \%$ (Maass \& Peissker, 1998). Taking into account economic, environmental and technical advantages and disadvantages of various regeneration methods, solvent extraction seems to be a reasonable solution for hot-dip galvanizing plants.

Among various investigated extractants, phosphonium ILs have been selected as potentially effective organic phases that are more stable than imidazolium ILs. Model aqueous feeds contained various amounts of $\mathrm{Zn}^{2+}, 1.8 \%(0.58 \mathrm{M}) \mathrm{HCl}$ and a constant concentration of chloride anions $(5 \mathrm{M})$.

$[\mathrm{QP}][\mathrm{Cl}]$ and $[\mathrm{QP}][\mathrm{Bis}]$ extract quickly and almost completely most chlorocomplexes of the metals studied (extraction efficiency near 100\%). They are effective and prospective extractants. Salts with more hydrophobic anions $\left[\mathrm{BF}_{4}^{-}\right]$extract about $60 \%$ of $\mathrm{Zn}^{2+}$, while $[\mathrm{QP}]\left[\mathrm{Tf}_{2} \mathrm{~N}\right]$, as having the most hydrophobic anion, poorly extracts metal ions. The metal ion transfer to the organic phase is influenced by the type of acid, electrolyte and IL concentration. The affinity of $[\mathrm{QP}]\left[\mathrm{Tf}_{2} \mathrm{~N}\right]$ phase to the aqueous phase is very low and the transfer of $\mathrm{Zn}^{2+}$ species is difficult. Water content in the organic phase after extraction confirms changes in the hydrophilicity of the IL phase, which increases in the following order: $[\mathrm{QP}]\left[\mathrm{Tf}_{2} \mathrm{~N}\right]$ in toluene $<[\mathrm{QP}]\left[\mathrm{Tf}_{2} \mathrm{~N}\right]$ in $\mathrm{TBP}<[\mathrm{QP}][\mathrm{Cl}]$ in toluene $<[\mathrm{QP}][\mathrm{Cl}]$ in butylene carbonate. When toluene is replaced with butylene carbonate no decrease in $\mathrm{Zn}^{2+}$ extraction is observed and this system is more environmentally friendly.

Extraction efficiency of the phosphonium ILs decreases with increasing hydrophobicity of the anion in the following sequence (Nowak et al., 2010): $[\mathrm{QP}][\mathrm{Cl}]>[\mathrm{QP}][\mathrm{Br}]>[\mathrm{QP}][\mathrm{Bis}]>$ $[\mathrm{QP}]\left[\mathrm{BF}_{4}\right]>[\mathrm{QP}]\left[\mathrm{PF}_{6}\right]>[\mathrm{QP}]\left[\mathrm{Tf}_{2} \mathrm{~N}\right]$. The dependence is also observed for the extraction with pure ILs, as it is mentioned for $\mathrm{Zn}^{2+}$ and $\mathrm{Fe}^{3+}$ extraction with imidazolium salts (Perez de los Rios et al., 2010). Due to low extraction of $\mathrm{Zn}^{2+}[\mathrm{QP}]\left[\mathrm{Tf}_{2} \mathrm{~N}\right]$ cannot be considered as an effective extractant in the system studied (Figs. 2 and 3 ). 


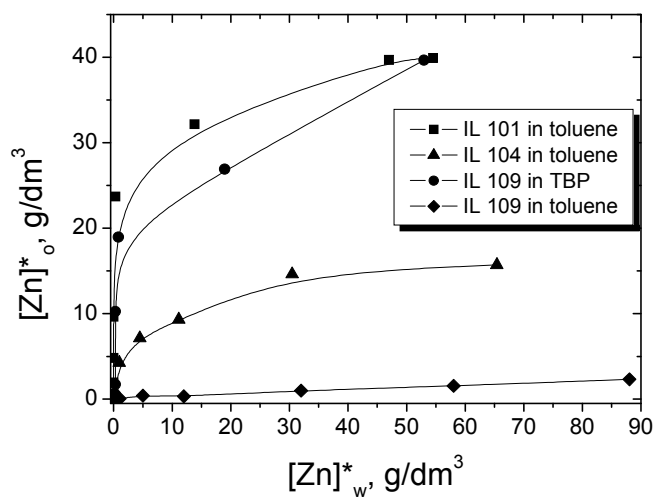

Fig. 2. Isotherms of $\mathrm{Zn}^{2+}$ extraction with various phosphonium IL/solvent mixtures.

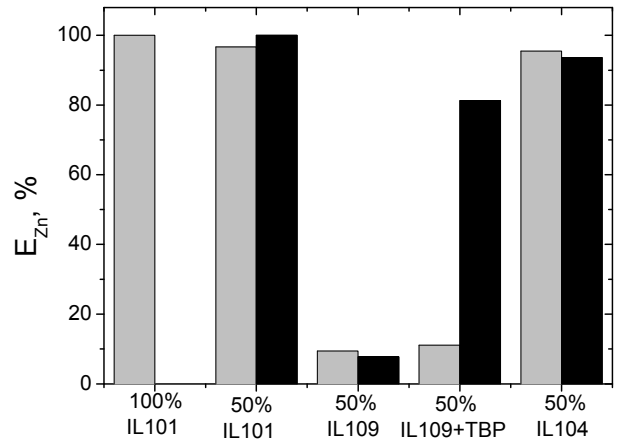

Fig. 3. Percentage extraction of $\mathrm{Zn}^{2+}$ with various phosphonium ILs from feed containing $0.58 \mathrm{M} \mathrm{HCl}(\boldsymbol{\square})$ and without $\mathrm{HCl}(\boldsymbol{\square})$ (Regel-Rosocka et al., 2006).

$[\mathrm{QP}][\mathrm{Cl}]$ is selected as the most effective extractant among the phosphonium ILs studied (Figs. 2 and 3). Extraction equilibrium is achieved in 5 minutes. It transfers more than $95 \%$ of $\mathrm{Zn}^{2+}$, and up to $80 \% \mathrm{Fe}^{2+}$ from the individual metal ion solutions. Twofold molar excess of the extractant over $\mathrm{Zn}^{2+}$ is necessary for efficient extraction $(100 \%)$. Moreover, $\mathrm{Zn}^{2+}$ extraction is preferred over $\mathrm{Fe}^{2+}$ when both are present in a mixture. The kinetics of both $\mathrm{Zn}^{2+}$ and $\mathrm{Fe}^{2+}$ extraction is very fast, and can be successfully applied to separate $\mathrm{Zn}^{2+}$ from $\mathrm{Fe}^{2+}$ when $\mathrm{Zn}^{2+}$ exceeds $\mathrm{Fe}^{2+}$ content in the feed. The presence of $\mathrm{HCl}$ in the feed enhances $\mathrm{Zn}^{2+}$ extraction (Fig. 3). The following reactions of $\mathrm{Zn}^{2+}$ extraction mechanism are proposed:

$$
\begin{gathered}
\mathrm{ZnCl}_{2(\mathrm{w})}+2[Q P][C l]_{(o)} \Leftrightarrow[Q P]_{2}\left[\mathrm{ZnCl} l_{4}^{-}\right]_{(o)} \\
\left.\mathrm{ZnCl}_{4(\mathrm{w})}^{2-}+2[Q P][C l]_{(o)} \Leftrightarrow[Q P]_{2}[\mathrm{ZnCl}]_{4}\right]_{(o)}+2 \mathrm{Cl}_{(\mathrm{w})}^{-}
\end{gathered}
$$

Moreover, the studies on stripping and regeneration of IL phase have revealed that sulphuric acid is the best stripping solution from among those studied. The ability to reuse the $[\mathrm{QP}][\mathrm{Cl}] /$ toluene mixture in several cycles of $\mathrm{Zn}^{2+}$ extraction-stripping has been proven. However, $\mathrm{Zn}^{2+}$ recovery from the organic phase needs three steps (Regel-Rosocka, 2009). 


\subsubsection{Extraction of $\mathbf{P d}^{2+}$}

Solvent extraction is proposed as a suitable method for PGMs (platinum group metals) recovery from low concentrated sources. Several extractants have been studied and proposed, e.g., hydroxyoximes, alkyl derivatives of 8-hydroxyquinoline, dialkyl sulphides, hydrophobic amines and quaternary ammonium salts, derivatives of pyridine and pyridinecarboxamides. However, the problems of a slow extraction rate or low metal separation remain to be solved. Looking for extractants permitting possibly fastest extraction of $\mathrm{Pd}^{2+}$, two phosphonium ionic liquids, i.e., [QP][Cl] and [QP][Bis], have been used (Cieszynska et al., 2007; Cieszynska, 2010; Cieszynska \& Wisniewski, 2010, 2011). To overcome problems caused by the high viscosity of ILs, the mixtures with toluene have been used for extraction, similarly as for extraction of $\mathrm{Zn}^{2+}$.

Extraction of $\mathrm{Pd}^{2+}$ with $[\mathrm{QP}][\mathrm{Cl}]$ and [QP] $[\mathrm{Bis}]$ is very fast and the equilibrium is achieved after 5 minutes (Fig. 4) contrary to the case when dialkyl sulphides are used in conventional PGMs extraction. The increase in $\mathrm{HCl}$ concentration affects $\mathrm{Pd}^{2+}$ extraction, which decreases from more than 90 to near $50 \%$ for 0.1 and $3 \mathrm{M} \mathrm{HCl}$, respectively (Fig. 5). Moreover, spontaneous transfer of $\mathrm{Pd}^{2+}$ to the organic phase, controlled by diffusion, is observed that suggests great mobility of the interface system.

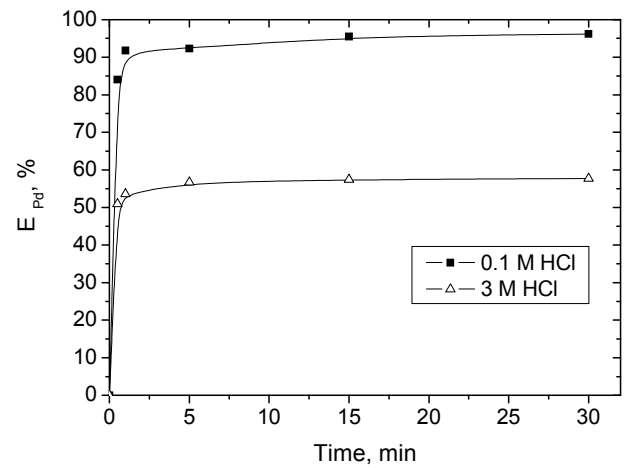

Fig. 4. Effect of contact time on $\mathrm{Pd}^{2+}$ extraction with [QP][Cl]: (feed: $5 \mathrm{mM} \mathrm{Pd}^{2+}, 0.1$ or $0.3 \mathrm{M}$ $\mathrm{HCl}$; organic: $5 \mathrm{mM}[\mathrm{QP}][\mathrm{Cl}]$ in toluene) (Cieszynska \& Wisniewski, 2010).

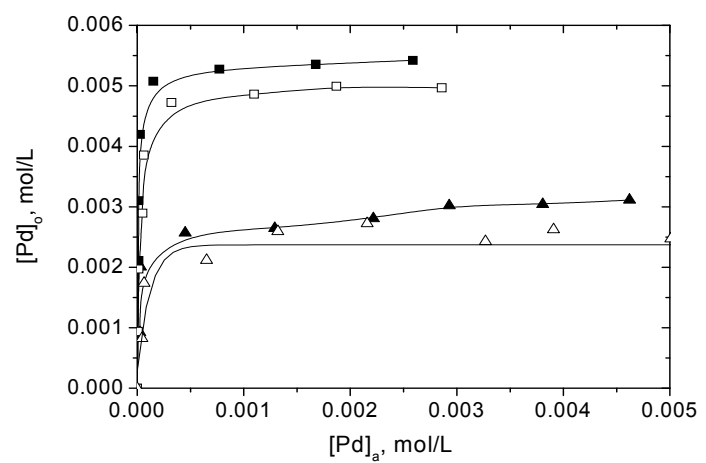

Fig. 5. The isotherms of $\mathrm{Pd}^{2+}$ extraction from $0.1(\boldsymbol{\bullet}, \square)$ and $3 \mathrm{M} \mathrm{HCl}(\boldsymbol{\Delta}, \triangle)$ with $[\mathrm{QP}][\mathrm{Cl}](\mathbf{\bullet}$, $\Delta)$ and $[\mathrm{QP}][\mathrm{Bis}](\square, \triangle)$; (feed: $1-8 \mathrm{mM} \mathrm{Pd}^{2+}$; organic: $5 \mathrm{mM}[\mathrm{QP}][\mathrm{Cl}]$ in toluene) (Cieszynska, 2010; Cieszynska \& Wisniewski, 2011). 
As a result of our investigation, the ion exchange mechanism has been proposed to describe the extraction of $\mathrm{Pd}^{2+}$ from 0.1 and $3 \mathrm{M} \mathrm{HCl}$ :

$$
\begin{aligned}
& {[\mathrm{QP}][\mathrm{Cl}]} \\
& \mathrm{PdCl}_{4(\mathrm{w})}^{2-}+[Q P][C l]_{(o)} \Leftrightarrow[Q P]_{2}\left[P d C l_{3}\right]_{(o)}+2 \mathrm{Cl}_{(\mathrm{w})}^{-} \\
& \mathrm{PdCl}_{4(\mathrm{w})}^{2-}+2[Q P][C l]_{(o)} \Leftrightarrow[Q P]_{2}\left[\mathrm{PdCl}_{4}\right]_{(o)}+2 \mathrm{Cl}_{(\mathrm{w})}^{-} \\
& \mathrm{H}_{(\mathrm{w})}^{+}+\mathrm{PdCl}_{4(\mathrm{w})}^{2-}+[Q P][B i s]_{(o)} \Leftrightarrow[Q P]\left[\mathrm{PdCl}_{3}\right]_{(o)}+\mathrm{HBis}_{(o)}+\mathrm{Cl}_{(\mathrm{w})}^{-} \\
& 2 \mathrm{H}_{(\mathrm{w})}^{+}+\mathrm{PdCl}_{4(\mathrm{w})}^{2-}+2[Q P]\left[\mathrm{Bis}_{(o)} \Leftrightarrow[Q P]_{2}\left[\mathrm{PdCl}_{4}\right]_{(o)}+2 \mathrm{HBis}_{(o)}\right.
\end{aligned}
$$

On this basis, $[\mathrm{QP}]\left[\mathrm{PdCl}_{3}\right]$ and $[\mathrm{QP}]_{2}\left[\mathrm{PdCl}_{4}\right]$ are proposed as ion pairs formed in the organic phase by $\mathrm{Pd}^{2+}$. Consequently, the ionic bonds in the IL phase are very strong, which is a drawback when stripping the metal ions from the loaded IL with water. Different stripping phases have been examined (Table 8). Ammonia solution is found to be an effective one, resulting in almost $100 \% \mathrm{Pd}^{2+}$ stripped from the loaded IL in one step.

\begin{tabular}{cc}
\hline Stripping solution & $\mathrm{S}_{\mathrm{Pd}}(\%)$ \\
\hline $0.5 \mathrm{M} \mathrm{H}_{2} \mathrm{SO}_{4}$ & 1.3 \\
$0.5 \mathrm{M} \mathrm{HCl}$ & 10.3 \\
$1 \mathrm{M} \mathrm{HCl}$ & 22.0 \\
$3 \mathrm{M} \mathrm{HCl}$ & 38.6 \\
$0.5 \mathrm{M} \mathrm{NH}_{4} \mathrm{OH}$ & 97.1 \\
\hline
\end{tabular}

Table 8. Percentage stripping $\left(\mathrm{S}_{\mathrm{Pd}}\right)$ of $\mathrm{Pd}^{2+}$ stripping from loaded $[\mathrm{QP}][\mathrm{Cl}]$ with various stripping solutions (Cieszynska, 2010; Cieszynska \& Wisniewski, 2010).

Regeneration of spent IL phases and their reuse in extraction is an important economical and ecological issue. Recycling of $0.005 \mathrm{M}[\mathrm{QP}][\mathrm{Cl}]$, loaded with $\mathrm{Pd}^{2+}$, was tested in 5 cycles of extraction (one step) and stripping (two steps with $0.5 \mathrm{M} \mathrm{NH}_{4} \mathrm{OH}$ ). After this procedure percentage extraction of $\mathrm{Pd}^{2+}$ does not change and remains 98 and 55\% for the feed containing 0.1 and $3 \mathrm{M} \mathrm{HCl}$, respectively (Cieszynska, 2010; Cieszynska \& Wisniewski, 2011). $[\mathrm{QP}][\mathrm{Cl}]$ is a stable extractant that can be regenerated and used again for efficient extraction of $\mathrm{Pd}^{2+}$.

To sum up, the presented extraction data indicate that $[\mathrm{QP}][\mathrm{Cl}]$ and $[\mathrm{QP}][\mathrm{Bis}]$ can be considered as active extractants for the extraction of metal chlorocomplexes.

\subsubsection{Extraction of $\mathrm{Co}^{2+}$}

Extraction of $\mathrm{Co}^{2+}$ can be given as another example to confirm the usefulness of phosphonium ILs in liquid-liquid extraction. Selective separation of $\mathrm{Co}^{2+}$ and $\mathrm{Ni}^{2+}$ in hydrometallurgical processes has been investigated for many years. Their chemical affinity means that their behaviour is similar which makes problems with their separation. Both $\mathrm{Ni}^{2+}$ and $\mathrm{Co}^{2+}$ form divalent ions hydrated by six water molecules in diluted aqueous solutions. The ratio of water exchange for $\mathrm{Co}^{2+}$ is much greater than for $\mathrm{Ni}^{2+}$, therefore the complexing ion is more easily formed with $\mathrm{Co}^{2+}$ than $\mathrm{Ni}^{2+}$. Moreover, $\mathrm{Co}^{2+}$ in the divalent state in high electrolyte concentrations tends to exhibit a tetrahedral rather than an octahedral configuration, giving it six coordinated sites.

As Cyanex 272 is a well known extractant for $\mathrm{Co}^{2+}$ ions, Cyphos IL 104, that is a derivative of Cyanex 272, has been applied for cobalt chloride solutions. Efficiency of extraction with both $[\mathrm{QP}][\mathrm{Cl}]$ and $[\mathrm{QP}][\mathrm{Bis}]$ is much higher for $\mathrm{Co}^{2+}$ than $\mathrm{Ni}^{2+}$. 


\begin{tabular}{ccccccc}
\hline \multirow{2}{*}{ Aqueous phase } & \multicolumn{3}{c}{$[\mathrm{QP}][\mathrm{Cl}]$} & \multicolumn{3}{c}{$[\mathrm{QP}][\mathrm{Bis}]$} \\
& $\mathrm{D}_{\mathrm{Co}(\mathrm{II})}$ & $\mathrm{D}_{\mathrm{Ni}(\mathrm{II})}$ & $\mathrm{S}_{\mathrm{Co}(\mathrm{II}) / \mathrm{Ni}(\mathrm{II})}$ & $\mathrm{D}_{\mathrm{Co}(\mathrm{II})}$ & $\mathrm{D}_{\mathrm{Ni}(\mathrm{II})}$ & $\mathrm{S}_{\mathrm{Co}(\mathrm{II}) / \mathrm{Ni}(\mathrm{II})}$ \\
\hline $\mathrm{Ni}+\mathrm{Co}$; without $\mathrm{HCl}$ & 0.15 & 0.05 & 3.00 & 20.4 & 0.29 & 70.4 \\
$\mathrm{Ni}+\mathrm{Co}$ 0.1 M HCl & 0.15 & 0.05 & 3.00 & 0.18 & 0.03 & 6.00 \\
$\mathrm{Ni}+\mathrm{Co} ; 0.5 \mathrm{M} \mathrm{HCl}$ & 0.18 & 0.19 & 0.95 & 0.19 & 0.00 & 0.00 \\
\hline
\end{tabular}

Table 9. Distribution coefficients of metal ion between organic and aqueous phase and the selectivity of $\mathrm{Co}^{2+}$ over $\mathrm{Ni}^{2+}$

An increase in $\mathrm{HCl}$ concentration in the feed aqueous phases containing metal ions, negatively influences the extraction efficiency and selectivity (shown in Table 9). The stripping efficiency of $\mathrm{Co}^{2+}$ decreases in the following order of stripping phases: $2 \mathrm{M} \mathrm{H}_{2} \mathrm{SO}_{4}$ $(97 \%)>0.5 \mathrm{M} \mathrm{HCl}(96 \%)>0.25 \mathrm{M} \mathrm{H}_{2} \mathrm{SO}_{4}(84 \%)>4 \mathrm{M} \mathrm{HCl}(61 \%)>\mathrm{H}_{2} \mathrm{O}(39 \%)$, and for $\mathrm{Ni}^{2+}$ : $2 \mathrm{M} \mathrm{H}_{2} \mathrm{SO}_{4}(65 \%)>0.25 \mathrm{M} \mathrm{H}_{2} \mathrm{SO}_{4}(55 \%)>$ distilled water (39\%), while $\mathrm{HCl}$ does not strip $\mathrm{Ni}^{2+}$ ions from the loaded organic phase. On this basis sulphuric acid is selected as the most efficient stripping phase.

Spectrophotometric analysis allows the coordination of $\mathrm{Co}^{2+}$ complexes formed in the presence of chlorides to be determined and indicates a change from an octahedral complex in the aqueous phase into tetrahedral one, existing in the organic phase (Ma et al., 2008). $[\mathrm{QP}][\mathrm{Bis}]$ is very selective for $\mathrm{Co}^{2+}$ over $\mathrm{Ni}^{2+}$ in the aqueous solutions without $\mathrm{HCl}\left(\mathrm{E}_{\mathrm{Co}(\mathrm{II})}=\right.$ $95 \%$ at $\mathrm{pH}$ 6). The same transformation of metal complex coordination is observed during extraction from a mixture of metal ions.

The proposed equations describing $\mathrm{Co}^{2+}$ extraction mechanism are as follows:

$[\mathrm{QP}][\mathrm{Cl}]$

$$
\mathrm{CoCl}_{2(\mathrm{w})}+[Q P][C l]_{(o)} \Leftrightarrow[Q P]\left[\mathrm{CoCl}_{3}\right]_{(o)}
$$

$[\mathrm{QP}][\mathrm{Bis}]$

$$
\begin{gathered}
2 \mathrm{H}_{(\mathrm{w})}^{+}+\mathrm{CoCl}_{4(\mathrm{w})}^{2-}+2[Q P][C l]_{(o)} \Leftrightarrow[Q P]_{2}\left[\mathrm{CoCl}_{4}\right]_{(o)}+2 \mathrm{H}_{(w)}^{+}+2 \mathrm{Cl}_{(\mathrm{w})}^{-} \\
\mathrm{H}_{(\mathrm{w})}^{+}+\mathrm{CoCl}_{4(\mathrm{w})}^{2-}+[Q P][B i s]_{(o)} \Leftrightarrow[Q P]\left[\mathrm{CoCl}_{3}\right]_{(o)}+\mathrm{HBis}_{(o)}+\mathrm{Cl}_{(\mathrm{w})}^{-} \\
\mathrm{H}_{(\mathrm{w})}^{+}+\mathrm{CoCl}_{4(\mathrm{w})}^{2-}+[Q P][\mathrm{Bis}]_{(o)} \Leftrightarrow[Q P]_{2}\left[\mathrm{CoCl}_{4}\right]_{(o)}+\mathrm{HBis}_{(o)}
\end{gathered}
$$

Nevertheless, further studies should be carried out on the mechanism of $\mathrm{Co}^{2+}$ extraction with $[\mathrm{QP}][\mathrm{Bis}]$. It is known that $\mathrm{CoCl}_{4}{ }^{2-}$ is not stable in the aqueous phase, so the extraction could proceed in another way.

\section{Conclusions}

Ionic liquids, considered as 'green solvents', have been studied as potential solvents or carriers of metal ions in liquid-liquid extraction. Although recently their 'greenness' is questioned because of possible hydrolysis with formation of toxic HF or partial loss to the aqueous phase, they are still interesting and important compounds in metal processing. Further, mutual solubility of imidazolium ILs and aqueous phase, i.e., problems with extraction but also (when the solubility is too high) with loss of ILs must be pointed out as their limitations. Hence, a compromise between IL hydrophobicity and its extraction power must be achieved. Their potential lies in improvement of extraction efficiency, vast possibilities to design 'functionalised ILs', significant reduction in the volume of the low concentration aqueous streams and process intensification. 
Looking at literature data, it is obvious that imidazolium ILs are the best described and applied for a variety of metal ion systems. However, research on extraction with ammonium and phosphonium ILs has been developed in the last five years, and indicates successful application of some of them for separation of metal ions. There are still plenty of research to be pursued in the field of separation with phosphonium and new ammonium ILs, to describe their extraction behaviour, mechanism of metal ion, water and other species transfer to the organic phase. Additionally, their stability and regeneration in separation processes, particularly those operating in strongly acidic or basic solutions, should be investigated.

The mechanism of extraction with ILs in most cases differs from that in conventional solvents, and seems to be more complex. ILs prefer extraction of charged species and, as a result, most metal ions are transported to the IL phase according to the cation or anionexchange mechanism. It can be attributed to the unique ionic solvation environment and the ion-exchange capabilities of ILs that influence their specific extraction behaviour.

Finally, regeneration of ILs is recently highlighted as an important issue affecting their greenness. Not only stripping with various solutions but $\mathrm{pH}$ change and even electrowinning of metal ions are proposed. Nonetheless, it seems that ILs will be rather applied for special separation processes, but not on a large scale.

\section{Acknowledgment}

We thank Anna Cieszynska for an agreement to present some results from her doctoral thesis. We thank Cytec Industries Inc. for providing us with free samples of Cyphos ILs. This work was supported by the grant No. 32/067/11/DS.

\section{References}

Abbott, A.P.; Frisch, G.; Hartley, J. \& Ryder, K.S. (2011). Processing of Metals and Metal Oxides Using Ionic Liquids. Green Chem., Vol.13, pp. 471-481

Adams, C.J. (2002). Neoteric Solvents: an Examination of Their Industrial Attractiveness, In : Ionic Liquids. Industrial Applications for Green Chemistry, R.D. Rogers, K.R. Seddon (Eds.), Vol.818, 15-29, ACS, ISBN13: 978-08-41237-89-6, Washington

Bartsch, R.A.; Chun, S. \& Dzyuba, S.V. (2002). Ionic Liquids as Novel Diluents for Solvent Extraction of Metal Salts by Crown Ethers, In : Ionic Liquids. Industrial Applications for Green Chemistry, R.D. Rogers, K.R. Seddon (Eds.), Vol.818, 58-68, ACS, ISBN13: 978-08-41237-89-6, Washington

Belova, V.V.; Voshkin, A.A.; Egorova, N.S. \& A. I. Kholkin (2010). Extraction of Rare Earth Metals from Nitrate Solutions with a Binary Extractant Based on Cyanex 272. Russ. J. Inorg. Chem., Vol.55, No.4, pp. 629-633

Bradaric, C.J.; Downard, A.; Kennedy, C.; Robertson, A.J. \& Zhou, Y. (2003a). Phosphonium Ionic Liquids. The Strem Chemiker, Vol. XX, No.1, pp. 2-11

Bradaric, C.J.; Downard, A.; Kennedy, C.; Robertson, A.J. \& Zhou, Y. (2003b). Industrial Preparation of Phosphonium Ionic Liquids. Green Chem., Vol. 5, pp. 143-152

Campos, K.; Domingo, R.; Vincent, T.; Ruiz, M.; Sastre, A.M. \& Guibal, E. (2008a). Bismuth Recovery from Acidic Solutions Using Cyphos IL-101 Immobilized in a Composite Biopolymer Matrix. Water Res., Vol.42, No.14, pp. 4019-4031 
Campos, K.; Vincent, T.; Bunio, P.; Trochimczuk, A. \& Guibal, E. (2008b). Gold Recovery from $\mathrm{HCl}$ Solutions Using Cyphos IL-101 (a Quaternary Phosphonium Ionic Liquid) Immobilized in Biopolymer Capsules. Solvent Extr. Ion Exch., Vol.26, No.5, pp. $570-601$

Chun, S.; Dzyuba, S.V. \& Bartsch, R.A. (2001). Influence of Structural Variation in RoomTemperature Ionic Liquids on the Selectivity and Efficiency of Competitive Alkali Metal Salt Extraction by a Crown Ether. Anal. Chem., Vol.73, pp. 3737-3741

Cieszynska, A.; Regel-Rosocka, M. \& Wisniewski, M. (2007). Extraction of Palladium(II) Ions from Chloride Solutions with Phosphonium Ionic Liquid Cyphos IL101. Pol. J. Chem. Technol., Vol.9, No.2, pp. 99-101

Cieszynska, A. \& Wisniewski, M. (2010). Extraction of Palladium(II) from Chloride Solutions with Cyphos IL 101/Toluene Mixtures as Novel Extractant. Sep. Purif. Technol., Vol.73, pp. 202-207

Cieszynska, A. (2010). Extraction of the Palladium(II) in the Presence of Selected Metals from Aqueous Chloride Solutions with Phosphonium Extractants. Doctoral thesis, Poznan (in Polish).

Cieszynska, A. \& Wisniewski, M. (2011). Selective Extraction of Palladium(II) from Hydrochloric Acid Solutions with Phosphonium Extractants. Sep. Purif. Technol. (after revision).

Cocalia, V.A.; Holbrey, J.D.; Gutowski, K.E.; Bridges, N.J. \& Rogers, R.D. (2005a). Separations of Metal Ions Using Ionic Liquids: the Challenges of Multiple Mechanisms. Proceedings of International Solvent Extraction Conference, ISBN 7900692-02-9, Beijing, September 2005

Cocalia, V.A.; Jensen, M.P.; Holbrey, J.D.; Spear, S.K.; Stepinski, D. \& Rogers, R.D. (2005b) Identical Extraction Behaviour and Coordination of Trivalent or Hexavalent fElement Cations Using Ionic Liquid and Molecular Solvents. Dalton Trans., Vol.2005, 1966-1971

Correia, M.J.N.; Marques, M.M.; Ismael, M.R. \& Reis, M.T.A. (2005). Ionic Liquids as Extractants of Phenolic Compounds and Metal Ions: Influence of the Type of Ionic Liquid. Proceedings of International Solvent Extraction Conference, ISBN 7-900692-02-9, Beijing, September 2005

Dai, S.; Ju, Y.H. \& Barnes, C.E. (1999). Solvent Extraction of Strontium Nitrate by a Crown Ether Using Room-Temperature Ionic Liquids. J. Chem. Soc., Dalton Trans., Vol.1999, pp. 1201-1202

Del Sesto, R.E.; Corley, C.; Robertson A. \& Wilkes, J.S. (2005). Tetraalkylphosphonium-Based Ionic Liquids. J. Organometall. Chem., Vol.690, pp. 2536-2542

Dietz, M.L. \& Dzielawa, J.A. (2001). Ion-Exchange as a Mode of Cation Transfer into RoomTemperature Ionic Liquids Containing Crown Ethers: Implications for the "Greenness" of Ionic Liquids as Diluents in liquid-Liquid Extraction. Chem. Commun., Vol.2001, pp. 2124-2125

Dietz, M.L.; Dzielawa, J.A.; Laszak, I.; Young, B.A. \& Jensen, M.P. (2003). Influence of Solvent Structural Variations on the Mechanism of Facilitated Ion Transfer into Room-Temperature Ionic Liquids. Green Chem., Vol.5, No.6, pp. 682-685

Dietz, M.L. \& Stepinski, D.C., (2005). A Ternary Mechanism for the Facilitated Transfer of Metal Ions into Room-Temperature Ionic Liquids (RTILs): Implications for the "Greenness" of RTILs as Extraction Solvents. Green Chem., Vol.7, pp. 747-750 
Dietz, M.L. (2006). Ionic Liquids as Extraction Solvents: Where do We Stand? Sep. Purif. Technol., Vol.41, pp. 2047-2063

Dietz, M.L.; Jakab, S.; Yamato, K. \& Bartsch, R.A. (2008). Stereochemical Effects on the Mode of Facilitated Ion Transfer into Room-Temperature Ionic Liquids. Green Chem., Vol.10, pp. 174-176

Dietz, M.L. \& Stepinski, D.C., (2008). Anion Concentration-Dependent Partitioning Mechanism in the Extraction of Uranium into Room-Temperature Ionic Liquids. Talanta, Vol.75, pp. 598-603

Domanska, U. \& Rekawek A. (2009). Extraction of Metal Ions from Aqueous Solutions Using Imidazolium Based Ionic Liquids. J. Solution Chem., Vol.38, pp. 739-751

Egorov, V.M.; Djigailo, D.I.; Momotenko, D.S.; Chernyshov, D.V.; Torocheshnikova, I.I.; Smirnova, S.V. \& Pletnev, I.V. (2010). Task-Specific Ionic Liquid Trioctylmethylammonium Salicylate as Extraction Solvent for Transition Metal Ions. Talanta, Vol.80, No.3, pp. 1177-1182

Gallardo, V.; Navarro, R.; Saucedo, I.; Ávila, M. \& Guibal, E. (2008). Zinc(II) Extraction from Hydrochloric Acid Solutions Using Amberlite XAD-7 Impregnated with Cyphos IL 101 (Tetradecyl(trihexyl)phosphonium Chloride). Sep. Sci. Technol., Vol.43, No.9-10, pp. $2434-2459$

Giridhar, P.; Venkatesan, K.A.; Srinivasan, T.G. \& Vasudewa Rao, P.R. (2005). Extraction of Uranium(VI) from Nitric Acid Medium by $1.1 \mathrm{M}$ Tri-n-butylphosphonate in Ionic Liquid Diluent. J. Radioanalytical Nuc. Chem., Vol.265, pp. 31-38

Giridhar, P.; Venkatesan, K.A.; Srinivasan, T.G. \& Vasudeva Rao, P.R. (2006). Extraction of Fission Palladium by Aliquat 336 and Electrochemical Studies on Direct Recovery from Ionic Liquid Phase. Hydrometallurgy, Vol.81, pp. 30-39

Guibal, E.; Gavilan, Campos, K.; Bunio, P.; Vincent, T. \& Trochimczuk, A. (2008). CYPHOS IL 101 (Tetradecyl(trihexyl)phosphonium Chloride) Immobilized in Biopolymer Capsules for $\mathrm{Hg}$ (II) Recovery from HCl Solutions. Sep. Sci. Technol., Vol.43, No.9-10, pp. $2406-2433$

Han, X. \& Armstrong, D.W. (2007). Ionic Liquids in Separations. Acc. Chem. Res., Vol.40, pp. 1079-1086

Haverlock, T.J.; Bonnesen, P.V.; Sachleben, R.A. \& Moyer, B.A. (2000). Analysis of Equilibria in the Extraction of Cesium Nitrate by Calix[4]arene-bis(t-octylbenzo-crown-6) in 1,2-Dichloroethane. J. Inclusion Phenom. Macrocyclic Chem., Vol.36, pp. 21-37

Holbrey, J.D. \& Seddon, K.R. (1999). Ionic Liquids. Clean Products and Processes, Vol.1, pp. $223-236$

Holbrey, J.D. \& Rogers, R.D. (2002). Green Chemistry and Ionic Liquids: Synergies and Ionies. In : Ionic Liquids. Industrial Applications for Green Chemistry, R.D. Rogers, K.R. Seddon (Eds.), Vol.818, 2-14, ACS, ISBN13: 978-08-41237-89-6, Washington

Hunddleston, J.G.; Willauer, H.D.; Swatloski, R.P.; Visser, A.E. \& Rogers, R.D. (1998). Room Temperature Ionic Liquids as Novel Media for “Clean" Liquid-Liquid Extraction. Chem. Commun., Vol.1998, pp. 1765-1766

Jensen, M.P.; Dzielawa, J.A.; Rickert P. \& Dietz, M.L. (2002). EXAFS Investigations of the Mechanism of Facilitated Ion Transfer into a Room-Temperature Ionic Liquid. J. Am. Chem. Soc., Vol.124, pp. 10664-10665 
Jensen, M.P.; Neuefeind, J.; Beitz, J.V.; Skanthakumar, S. \& Soderholm, L. (2003). Mechanisms of Metal Ion Transfer into Room-Temperature Ionic Liquids: the Role of Anion Exchange. J. Am. Chem. Soc., Vol.125, pp. 15466-15473

Kejun, L.; Yen, W.T.; Shibayama, A.; Miyazaki, T. \& Fujita T. (2004). Gold Extraction from Thiosulfate Solution Using Trioctylmethylammonium Chloride. Hydrometallurgy, Vol. 73, pp. 41-53

Kogelnig, D.; Stojanovic, A.; Galanski, M.; Groessl, M.; Jirsa, F.; Krachler, R. \& Keppler, B.K. (2008). Greener Synthesis of New Ammonium Ionic Liquids and Their Potential as Extracting Agents. Tetrahedron Lett., Vol.49, No.17, pp. 2782-2785

Kogelnig, D.; Stojanovic, A.; Jirsa, F.; Körner, W.; Krachler, R. \& Keppler, B.K. (2010). Transport and Separation of Iron(III) from Nickel(II) with the Ionic Liquid Trihexyl(tetradecyl)phosphonium Chloride. Sep. Purif. Technol., Vol.72, No.1, pp. $56-60$

Kosmulski, M.; Marczewska-Boczkowska, K. \& Saneluta, C. (2002). Low Temperature Ionic Liquids - a Laboratory Curiosity or a Technological Revolution? Przem. Chem., Vol.81, pp. 106-110 (in Polish)

Kozonoi, N. \& Ikeda, Y. (2007). Extraction Mechanism of Metal Ion from Aqueous Solution to the Hydrophobic Ionic Liquid, 1-Butyl-3-methylimidazolium Nonafluorobutanesulfonate. Monatshefte fur Chemie, Vol.138, pp. 1145-1151

Luo, H.; Dai, S. \& Bonnesen, P.V. (2004a). Solvent Extraction of $\mathrm{Sr}^{2+}$ and $\mathrm{Cs}^{+}$Based on RoomTemperature Ionic Liquids Containing Monoaza-Substituted Crown Ethers. Anal. Chem., Vol.76, pp. 2773-2779

Luo, H.; Dai, S.; Bonnesen, P.V.; Buchanan III, A.C.; Holbrey, J.D.; Bridges, N.J. \& Rogers, R.D. (2004b). Extraction of Cesium Ions from Aqueous Solutions Using Calix[4]arene-bis(tert-octylbenzo-crown-6) in Ionic Liquids. Anal. Chem., Vol.76, pp. 3078-3083

Luo, H.; Dai, S.; Bonnesen, P.V. \& Buchanan III, A.C. (2006a). Separation of Fission Products Based on Ionic Liquids : Task-specific Ionic Liquids Containing an Aza-crown Ether Fragment. J. Alloy Compd., Vol.418, 195-199

Luo, H.; Dai, S.; Bonnesen, P.V., Haverlock T.J., Moyer B.A \& Buchanan III, A.C. (2006b). A Striking Effect of Ionic-Liquid Anions in the Extraction of $\mathrm{Sr}^{2+}$ and $\mathrm{Cs}^{+}$by Dicyclohexano-18-Crown-6. Solvent Extr. Ion Exch., Vol.24, pp. 19-31

Ma, H.; Wan, C. \& Zewail, A.H. (2008). Dynamics of Ligand Substitution in Labile Cobalt Complexes Resolved by Ultrafast T-jump. Proceedings of the National Academy of Sciences of the USA, Vol.105, No.35, pp. 12754-12757

Maass, P. \& Peissker, P. (1998). Hot-dip Galvanizing. Agencja Wydawnicza Placet, ISBN 97883-85428-28-3, Warsaw (in Polish)

Marszalkowska, B.; Regel-Rosocka, M.; Nowak, Ł. \& Wisniewski, M. (2010). Quaternary Phosphonium Salts as Effective Extractants of Zinc(II) and Iron(III) Ions from Acidic Pickling Solutions. Pol. J. Chem. Technol., Vol.12, No.4, pp. 1-5

Nakashima, K.; Kubota, F.; Maruyama, T. \& Goto, M. (2003). Ionic Liquids as a Novel Solvent for Lanthanide Extraction. Anal. Sci., Vol.19, pp. 1097-1098

Nakashima, K.; Kubota, F.; Maruyama, T. \& Goto, M. (2005). Feasibility of Ionic Liquids as Alternative Separation Media for Industrial Solvent Extraction Processes. Ind. Eng. Chem. Res., Vol.44, pp. 4368-4372 
Nowak, L.; Regel-Rosocka, M.; Marszałkowska, B. \& Wisniewski, M. (2010). Removal of $\mathrm{Zn}$ (II) from Chloride Acidic Solutions with Hydrophobic Quaternary Salts. Pol. J. Chem. Technol., Vol.12, No.3, pp. 24-28

Papaiconomou, N.; Lee, J.M.; Salminen, J.; von Stosch, M. \& Prausnitz, J.M. (2008). Selective Extraction of Copper, Mercury, Silver, and Palladium Ions from Water Using Hydrophobic Ionic Liquids. Ind. Eng. Chem. Res., Vol.47, pp. 5080-5086

Perez de los Rios, A.; Hernandez-Fernandez, F.J.; Sanchez-Segado, S.; Lozano, L.J.; Moreno, J.I. \& Godinez, C. (2010). Selective Separation of $\mathrm{Zn}(\mathrm{II})$ and Fe(III) from Acidic Media Using Ionic Liquids as Sole Extraction Agents. Chem. Eng. Transactions, Vol.21, pp. 625-630, ISBN 978-88-95608-05-1

Pernak, J. (2003). Ionic Liquids. Compounds for the 21st Century. Przem. Chem., Vol. 82, pp. 521-524 (in Polish)

Pernak, J.; Stefaniak, F. \& Weglewski, J. (2005). Phosphonium Acesulfamate Based Ionic Liquids. Eur. J. Org. Chem., Vol.2005, No.4, pp. 650-652

Regel-Rosocka, M.; Cieszyńska K. \& Wiśniewski M. (2006). Extraction of Zinc(II) with Selected Phosphonium Ionic Liquids, Przem. Chem., Vol.85, pp. 651-654 (in Polish)

Regel-Rosocka, M.; Cieszynska, A. \& Wisniewski, M. (2007). Methods of Regeneration of Spent Pickling Solutions from Steel Treatment Plants. Pol. J. Chem. Technol., Vol.2, pp. $42-45$

Regel-Rosocka, M. (2009). Extractive Removal of Zinc(II) from Chloride Liquors with Phosphonium Ionic Liquids/Toluene Mixtures as Novel Extractants, Sep. Purif. Technol., Vol.66, pp. 19-24

Regel-Rosocka, M. (2010). A Review on Methods of Regeneration of Spent Pickling Solutions from Steel Processing. J. Hazard. Mater., Vol.177, No.1-3, pp. 57-69

Rickert, P.G.; Stepinski, D.C.; Rausch, D.J.; Bergeron, R.M.; Jakab, S. \& Dietz, M.L. (2007). Solute-Induced Dissolution of Hydrophobic Ionic Liquids in Water. Talanta, Vol.72, pp. $315-320$

Sato, T.; Takayanagi, T. \& Sato, K. (2010). Liquid-Liquid Extraction of Palladium(II) from Hydrochloric Acid Solutions by High Molecular Weight Amines. Solvent Extr. Res. Dev., Japan, Vol.17, pp. 95-110

Seddon, K.R.; Stark, A. \& Torres, M.J. (2000). Influence of Chloride, Water, and Organic Solvents on the Physical Properties of Ionic Liquids. Pure Appl. Chem., Vol.72, pp. 2275-2287

Shen, Y.; Tan, X.; Wang, L. \& Wu, W. (2011). Extraction of the Uranyl Ion from the Aqueous Phase into Anionic Liquid by Diglycolamide. Sep. Purif. Technol., doi: 10.1016/j.seppur.2011.01.042, in press.

Shimojo, K. \& Goto, M. (2004). Solvent Extraction and Stripping of Silver Ions in RoomTemperature Ionic Liquids Containing Calixarenes. Anal. Chem., Vol.76, pp. 50395044

Shimojo, K.; Kurahashi, K. \& Naganawa, H. (2008). Extraction Behavior of Lanthanides Using a Diglycolamide Derivative TODGA in Ionic Liquids. Dalton Trans., No.37, pp. 5083-5088

Srncik, M.; Kogelnig, D.; Stojanovic, A.; Körner, W.; Krachler, R. \& Wallner, G. (2009). Uranium Extraction from Aqueous Solutions by Ionic Liquids. Appl. Radiat. Isotopes, Vol.67, No.12, pp. 2146-2149 
Stepinski, D.C.; Jensen, M.P.; Dzielawa, J.A. \& Dietz, M.L. (2005). Synergistic Effects in the Facilitated Transfer of Metal Ions into Room-Temperature Ionic Liquids. Green Chem., Vol.7, pp. 151-158

Stepinski, D.C.; Vandegrift, G.F.; Shkrob, I.A.; Wishart, J.F.; Kerr, K.; Dietz, M.L.; Qadah, D.T.D. \& Garvey, S.L. (2010). Extraction of Tetra-Oxo Anions into a Hydrophobic, Ionic Liquid-Based Solvent without Concomitant Ion Exchange. Ind. Eng. Chem. Res., Vol.49, pp. 5863-5868

Stojanovic, A.; Kogelnig, D.; Fischer, L.; Hann, S.; Galanski, M.; Groessl, M.; Krachler, R. \& Keppler, B. K. (2010). Phosphonium and Ammonium Ionic Liquids with Aromatic Anions: Synthesis, Properties, and Platinum Extraction. Aust. J. Chem., Vol.63, pp. 511-524

Sun, X.; Ji, Y.; Zhang, L.; Chen, J. \& Li, D. (2010). Separation of Cobalt and Nickel Using Inner Synergistic Extraction from Bifunctional Ionic Liquid Extractant (Bif-ILE). J. Hazard. Mater., Vol.182, pp. 447-452

Swatloski, R.P.; Holbrey J.D. \& Rogers, R.D. (2003). Ionic Liquids Are Not Always Green: Hydrolysis of 1-Butyl-3-methylimidazolium Hexafluorophosphate. Green Chem., Vol.5, pp. 361-363

Turanov, A.N.; Karndashev, V.K. \& Baulin, V.E. (2008). Effect of Ionic Liquids on the Extraction of Rare-earth Elements by Bidentate Neutral Organophosphorus Compounds from Chloride Solutions. Russ. J. Inorg. Chem., Vol.53, pp. 970-975

Vidal, S.T.M.; Correia, M.J.N.; Marques, M.M.; Ismael, M.R. \& Reis, M.T.A. (2004). Studies on the Use of Ionic Liquids as Potential Extractants of Phenolic Compounds and Metal Ions. Sep. Sci. Technol., Vol.39, pp. 2155-2169

Visser, A.E.; Swatloski, R.P.; Reichert, W.M.; Griffin, S.T. \& Rogers, R.D. (2000). Traditional Extractants in Nontraditional Solvents: Groups 1 and 2 Extraction by Crown Ethers in Room-Temperature Ionic Liquids. Ind. Eng. Chem. Res., Vol.39, pp. 3596-3604

Visser, A.E.; Holbrey, J.D. \& Rogers, R.D. (2001a). Hydrophobic Ionic Liquids Incorporating $\mathrm{N}$-alkylisoquinilinium Cations and Their Utilization in Liquid-Liquid Separations. Chem. Commun., pp. 2484-2485

Visser, A.E.; Swatloski, R.P.; Griffin, S.T.; Hartman, D.H. \& Rogers, R.D. (2001b). Liquid/Liquid Extraction of Metal Ions in Room Temperature Ionic Liquids. Sep. Sci. Technol., Vol.36, pp. 785-804

Visser, A.E.; Swatloski, R.P.; Reichert, W.M.; Mayton, R.; Sheff, S.; Wierzbicki, A.; Davis, J.H. \& Rogers, R.D. (2001c). Task-specific Ionic Liquids for the Extraction of Metal Ions from Aqueous Solutions. Chem. Commun., Vol.2001, pp. 135-136

Visser, A.E.; Holbrey, J.D. \& Rogers, R.D. (2002a). Room Temperature Ionic Liquids as Alternatives to Traditional Organic Solvents in Solvent Extraction. Proceedings of Solvent Extraction Conference, ISBN 1-919783-24-5, Cape Town, March 2002

Visser, A.E.; Swatloski, R.P.; Reichert, W.M.; Mayton, R.; Sheff, S.; Wierzbicki, A.; Davis, Jr., J.H. \& Rogers, R.D. (2002b). Task-Specific Ionic Liquids Incorporating Novel Cations for the Coordination and Extraction of $\mathrm{Hg}^{2+}$ and $\mathrm{Cd}^{2+}$ : Synthesis, Characterization, and Extraction Studies. Environ. Sci. Technol., Vol.36, pp. 25232529

Visser, A.E.; Jensen, M.P.; Laszak, I.; Nash, K.L.; Choppin, G.R. \& Rogers, R.D. (2003). Uranyl Coordination Environment in Hydrophobic Ionic Liquids: An in Situ Investigation. Inorg. Chem., Vol.42, pp. 2197-2199 
Visser, A.E. \& Rogers, R.D. (2003). Room-Temperature Ionic Liquids: New Solvents for felement Separations and Associated Solution Chemistry. J. Solid State Chem., Vol.171, pp. 109-113

Wei, G.T.; Yang, Z. \& Chen, C.J. (2003a). Room Temperature Ionic Liquid as a Novel Medium for Liquid/Liquid Extraction of Metal Ions. Anal. Chim. Acta, Vol.488, pp. 183-192

Wei, G.T.; Chen, C.J. \& Yang, Z. (2003b). Studies on Liquid-Liquid Extraction of Copper Ion with Room Temperature Ionic Liquid. Journal of Chinese Chemical Society, Vol.50, pp 1123-1130

Wionczyk, B. (2009). Effect of Temperature on the Extraction of Chromium(III) from Alkaline Aqueous Solutions with Trioctylmethylammonium Chloride (Aliquat 336). Solvent Extr. Ion Exch., Vol.27, No.3, pp. $423-446$

Zuo, Y.; Liu, Y.; Chen, J. \& Li, D.Q. (2008). The Separation of Cerium(IV) from Nitric Acid Solutions Containing Thorium(IV) and Lanthanides(III) Using Pure $\left[\mathrm{C}_{8} \mathrm{mim}_{\mathrm{P}} \mathrm{PF}_{6}\right.$ as Extracting Phase. Ind. Eng. Chem. Res., Vol.47, pp. 2349-2355

Zuo, Y.; Liu, Y.; Chena, J. \& Lia, D.Q. (2009). Extraction and Recovery of Cerium(IV) along with Fluorine(I) from Bastnasite Leaching Liquor by DEHEHP in $\left[\mathrm{C}_{8} \mathrm{mim}\right] \mathrm{PF}_{6} . J$. Chem. Technol. Biotechnol., Vol.84, pp. 949-956 
APPUications of

IONIC LIQUIDS IN SCIENCE

AND TECHNOLOGY

Edand by Scott Handy

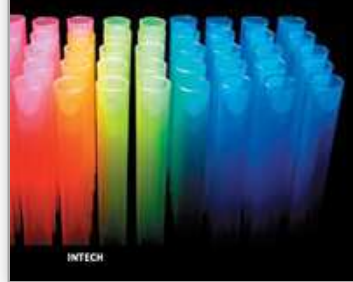

\section{Applications of lonic Liquids in Science and Technology}

Edited by Prof. Scott Handy

ISBN 978-953-307-605-8

Hard cover, 516 pages

Publisher InTech

Published online 22, September, 2011

Published in print edition September, 2011

This volume, of a two volume set on ionic liquids, focuses on the applications of ionic liquids in a growing range of areas. Throughout the 1990s, it seemed that most of the attention in the area of ionic liquids applications was directed toward their use as solvents for organic and transition-metal-catalyzed reactions. Certainly, this interest continues on to the present date, but the most innovative uses of ionic liquids span a much more diverse field than just synthesis. Some of the main topics of coverage include the application of RTILs in various electronic applications (batteries, capacitors, and light-emitting materials), polymers (synthesis and functionalization), nanomaterials (synthesis and stabilization), and separations. More unusual applications can be noted in the fields of biomass utilization, spectroscopy, optics, lubricants, fuels, and refrigerants. It is hoped that the diversity of this volume will serve as an inspiration for even further advances in the use of RTILs.

\section{How to reference}

In order to correctly reference this scholarly work, feel free to copy and paste the following:

Magdalena Regel-Rosocka and Maciej Wisniewski (2011). Ionic Liquids in Separation of Metal lons from Aqueous Solutions, Applications of Ionic Liquids in Science and Technology, Prof. Scott Handy (Ed.), ISBN: 978-953-307-605-8, InTech, Available from: http://www.intechopen.com/books/applications-of-ionic-liquids-inscience-and-technology/ionic-liquids-in-separation-of-metal-ions-from-aqueous-solutions

\section{INTECH}

open science | open minds

\author{
InTech Europe \\ University Campus STeP Ri \\ Slavka Krautzeka 83/A \\ 51000 Rijeka, Croatia \\ Phone: +385 (51) 770447 \\ Fax: +385 (51) 686166 \\ www.intechopen.com
}

\author{
InTech China \\ Unit 405, Office Block, Hotel Equatorial Shanghai \\ No.65, Yan An Road (West), Shanghai, 200040, China \\ 中国上海市延安西路65号上海国际贵都大饭店办公楼405单元 \\ Phone: +86-21-62489820 \\ Fax: $+86-21-62489821$
}


(C) 2011 The Author(s). Licensee IntechOpen. This chapter is distributed under the terms of the Creative Commons Attribution-NonCommercialShareAlike-3.0 License, which permits use, distribution and reproduction for non-commercial purposes, provided the original is properly cited and derivative works building on this content are distributed under the same license. 